\title{
Quality and consistency of clinical practice guidelines for treating children with COVID-19
}

\author{
Qinyuan $\mathrm{Li}^{1 \# \wedge}$, Qi Zhou ${ }^{2,3 \#}$, Yangqin Xun ${ }^{3}$, Hui Liu ${ }^{4}$, Qianling Shi ${ }^{2}$, Zijun Wang ${ }^{3}$, Siya Zhao ${ }^{4}$, Xiao Liu ${ }^{4}$, \\ Enmei Liu ${ }^{1}$, Zhou Fu' ${ }^{1}$, Yaolong Chen ${ }^{3,5,6,7,8,9}$, Zhengxiu Luo ${ }^{1}$
}

${ }^{1}$ Department of Respiratory Medicine Children's Hospital of Chongqing Medical University, National Clinical Research Center for Child Health and Disorders, Ministry of Education Key Laboratory of Child Development and Disorders, Chongqing Key Laboratory of Pediatrics, Chongqing, China; ${ }^{2}$ The First School of Clinical Medicine, Lanzhou University, Lanzhou, China; ${ }^{3}$ Evidence-Based Medicine Center, School of Basic Medical Sciences, Lanzhou University, Lanzhou, China; ${ }^{4}$ School of Public Health, Lanzhou University, Lanzhou, China; ${ }^{5}$ Lanzhou University Institute of Health Data Science, Lanzhou, China; ${ }^{6}$ WHO Collaborating Centre for Guideline Implementation and Knowledge Translation, Lanzhou, China; ${ }^{7}$ GIN Asia, Lanzhou, China; ${ }^{8}$ Chinese GRADE Centre, Lanzhou, China; ${ }^{9}$ Lanzhou University, an Affiliate of the Cochrane China Network, Lanzhou, China

Contributions: (I) Conception and design: Z Luo, Y Chen, Q Li, Q Zhou; (II) Administrative support: Z Luo, Y Chen, E Liu, Z Fu; (III) Provision of study materials or patients: Z Luo, Y Chen, E Liu, Z Fu, Q Li, Q Zhou; (IV) Collection and assembly of data: Q Li, Q Zhou, Y Xun, H Liu, Q Shi, Z Wang; (V) Data analysis and interpretation: Q Li, Q Zhou, S Zhao, X Liu; (VI) Manuscript writing: All authors; (VII) Final approval of manuscript: All authors.

"These authors contributed equally to this work.

Correspondence to: Zhengxiu Luo, MD. Children's Hospital of Chongqing Medical University, No. 20 Jinyu Avenue, Yubei District, Chongqing 401122, China. Email: luozhengxiu816@163.com; Yaolong Chen, MD. Evidence-Based Medicine Center, School of Basic Medical Sciences, Lanzhou University, Lanzhou 730000, China. Email: chenyaolong@lzu.edu.cn.

Background: The Coronavirus Disease 2019 (COVID-19) pandemic negatively affects children's health. Many guidelines have been developed for treating children with COVID-19. The quality of the existing guidelines and the consistency of recommendations remains unknown. Therefore, we aim to review the clinical practice guidelines (CPGs) for children with COVID-19 systematically.

Methods: We systematically searched Medline, Embase, guideline-related websites, and Google. The Appraisal of Guidelines for Research and Evaluation II (AGREE II) tool and Reporting Items for practice Guidelines in HealThcare (RIGHT) checklist were used to evaluate the methodological and reporting quality of the included guidelines, respectively. The consistency of recommendations across the guidelines and their supporting evidence were analyzed.

Results: Twenty guidelines were included in this study. The mean AGREE II score and mean RIGHT reporting rate of the included guidelines were 37\% (range, 22-62\%) and 52\% (range, 31-89\%), respectively. As for methodological quality, no guideline was classified as high, one guideline (5\%) moderate, and 19 (95\%) low. In terms of reporting quality, one guideline (5\%) was rated as high, 12 guidelines (60\%) moderate, and seven (35\%) low. Among included guidelines, recommendations varied greatly in the use of remdesivir (recommend: $25 \%$, not recommend: $45 \%$, not report: 30\%), interferon (recommend: 15\%, not recommend: $50 \%$, not report: $35 \%$ ), glucocorticoids (recommend: $50 \%$, not recommend: $20 \%$, not report: $30 \%$ ), and intravenous immune globulin (recommend: $35 \%$, not recommend: $30 \%$, not report: $35 \%$ ). None of the guidelines cited clinical trials from children with COVID-19.

Conclusions: The methodological and reporting quality of guidelines for treating children with COVID-19 was not high. Recommendations were inconsistent across different guidelines. The supporting evidence from children with COVID-19 was very limited.

$\wedge$ ORCID: 0000-0002-4052-5747. 
Keywords: Clinical practice guidelines (CPGs); quality appraisal; consistency analysis; Coronavirus Disease 2019 (COVID-19); children

Submitted Oct 19, 2020. Accepted for publication Feb 04, 2021.

doi: $10.21037 / \mathrm{atm}-20-7000$

View this article at: http://dx.doi.org/10.21037/atm-20-7000

\section{Introduction}

Coronavirus Disease 2019 (COVID-19) caused by severe acute respiratory syndrome coronavirus 2 (SARS$\mathrm{CoV}-2$ ) has become a worldwide pandemic (1). Up to October 4, 2020, there have been 34,804,348 confirmed cases and 1,030,738 deaths reported to the World Health Organization (WHO) (2), and the numbers keep increasing. The disease seems to be milder in children compared with adults (3). Most cases of COVID-19 in children were thought to be asymptomatic or have mild clinical manifestations (3). However, the situation appears to be changing, infants and young children present more severe illness (4). Until recently, an unanticipated inflammatory syndrome related to COVID-19 rapidly emerged in children. These children showed features similar to atypical Kawasaki disease (KD). Critical cases may have coronary artery aneurysms (CAA), cardiac insufficiency, toxic shock, and even death (5). Management is mainly supportive care. Some studies suggested antiviral drugs, glucocorticoids, intravenous immunoglobulin (IVIG), and biologics for treating severe and critically ill cases $(5,6)$. Few clinical trials have performed in children with COVID-19, as most clinical trials have focused on adult patients. Therefore, whether these drugs could be used in children remains controversial. The treatment strategies varied in different medical institutions. Therefore, it is important to standardize the treatment of children with COVID-19.

Evidence-based clinical practice guidelines (CPGs) can improve the quality of health care and the prognosis of patients (7). Therefore, CPGs for treating children with COVID-19 are required. National and international organizations are increasingly developing their CPGs. Despite the increasing number, the quality of the existing guidelines, the consistency of recommendations, and their supporting evidence remain unknown. Low-quality and inconsistent recommendations may puzzle the pediatricians and cause incorrect decision making. Hence, we conducted this study to systematically evaluate the methodological and reporting quality of CPGs on the treatment of children with COVID-19, to analyze the consistency of recommendations and their supporting evidence across these CPGs, and to provide a reference for appropriate treatment and future guideline development.

We present this article in accordance with the PRISMA reporting checklist (available at http://dx.doi.org/10.21037/ atm-20-7000) (8).

\section{Methods}

\section{Data sources and search strategy}

We systematically searched Medline and Embase in cooperation with information retrieval experts (9). A manual search in guideline-related websites and Google was also performed. We limited the search to CPGs published from 1 January 2020 until 30 August 2020. The detailed search strategy was presented in Appendix 1.

\section{Eligibility criteria}

We included CPGs providing recommendations for treating children with COVID-19 and published in English. We excluded draft guidelines that were under development or not finalized, previous guidelines replaced by updated versions from the same organization, and guidelines for children with underlying diseases.

\section{Study selection}

Search results were imported into the specific bibliographic software EndNote and duplicates identified. Before the formal screening, a pilot of 50 random sample citations (from outside of the sample) was conducted to improve consistency. Then two reviewers $(\mathrm{QL}, \mathrm{ZW})$ independently screened all searched documents. The formal selection process consisted of three stages: (I) we used the predefined criteria to screen all titles and abstracts of studies and determined whether they were relevant to the research question; (II) once titles and abstracts were screened, the full text should be retrieved and screened to definitely decide whether the study fitted the eligibility criteria; (III) 
disagreements were resolved by discussion, or solved with a third reviewer (QZ), if needed.

\section{Data extraction}

To improve the agreements among reviewers, extraction of the guidelines was pre-piloted to ensure the comprehensiveness and scientificity of this process, and the standardized form has been modified and improved after the pilot. The following data were extracted using a standardized form: (I) basic information: developing organization, publication year, country, number of recommendations, systematic literature retrieval, evidence quality grading system, recommendation formulation method, funding body, and conflicts of interest; (II) recommendations for treatment and their supporting evidence. Data were extracted by two reviewers (QL, QS). Disagreements were discussed or solved with a third reviewers $(\mathrm{QZ})$.

\section{Quality appraisal of guidelines}

The Appraisal of Guidelines for Research and Evaluation II (AGREE II) tool (10-13) was used to evaluate the methodological quality of the included guidelines. It consisted of 23 items grouped into six domains (scope and purpose, stakeholder involvement, rigor of development, clarify and presentation, applicability, and editorial independence). Each item was given a score from 1 (strongly disagree) to 7 (strongly agree). The overall quality scores ranged from $0 \%$ to $100 \%$, and guidelines were classified as "high quality" if the AGREE II score was $>80 \%$, "moderate quality" if it was 50-80\%, and "low quality" if <50\% (14). Before the formal evaluation, all reviewers completed an online training tutorial to ensure standardization (10-13). Two rounds of pilot appraisals with four guidelines were conducted to achieve better consistency. The intraclass correlation coefficient (ICC) was used to test inter-rater reliability. Two reviewers (QL, HL) independently assessed each guideline. Table S1 presented the results of the AGREE II evaluation. Appendix 2 presented the formula used to calculate the AGREE II score.

The Reporting Items for practice Guidelines in HealThcare (RIGHT) checklist was used to analyze the reporting quality of the included guidelines (15). It contained 22 items (35 sub-items) grouped into seven domains (information, background, evidence, recommendations, review and quality assurance, funding and conflict-of-interest statements and management, and other information of the guideline). Each item was rated either as "reported" or "not reported". The "reported" option was used when the relevant information was provided in the guideline, whereas "not reported" indicated that the relevant information could not be found or was unclear. The guidelines were classified as "well-reported" if the reporting rate was $>80 \%$, "moderate-reported" if it was $50-80 \%$, and "low-reported" if $<50 \%$ (14). Two rounds of pilot assessment of four guidelines were completed and the ICC value was calculated. Two reviewers $(\mathrm{QL}$ and YX) independently assessed the adherence of the guidelines to the RIGHT checklist. Disagreements were discussed or solved with a third reviewers (QZ). Table S2 presented the results of the RIGHT checklist evaluation. Appendix 2 presented the formula used to calculate the RIGHT reporting rates.

\section{Comparison of recommendations}

We compared the following recommendations and their supporting evidence: the use of antivirus drugs, glucocorticoids, IVIG, biologics, antiplatelet and anticoagulation, antibiotics, noninvasive ventilation, convalescent plasma therapy, blood purification, extracorporeal membrane oxygenation (ECMO) therapy, and psychotherapy. We further analyzed the treatment type, indication, dosing regimen, course of treatment, numbers, and types of supporting evidence.

\section{Statistical analysis}

The categorical variables were presented as frequency and percentage, and the continuous variables were presented as mean \pm standard deviation (SD). RevMan 5.3 software was used to compare the differences between different subgroups, and the effect size of continuous variables was presented with a weighted mean difference (WMD) and its $95 \%$ confidence interval (CI). SPSS 25.0 software was used to calculate ICC values to test inter-rater reliability. ICC $<0.4$ indicated low reliability, ICC $>0.75$ indicated high reliability (16).

\section{Results}

\section{Basic information}

The ICC values for the pilot test using the AGREE II tool and the RIGHT checklist were 0.96 (95\% CI: 0.94-0.98) 


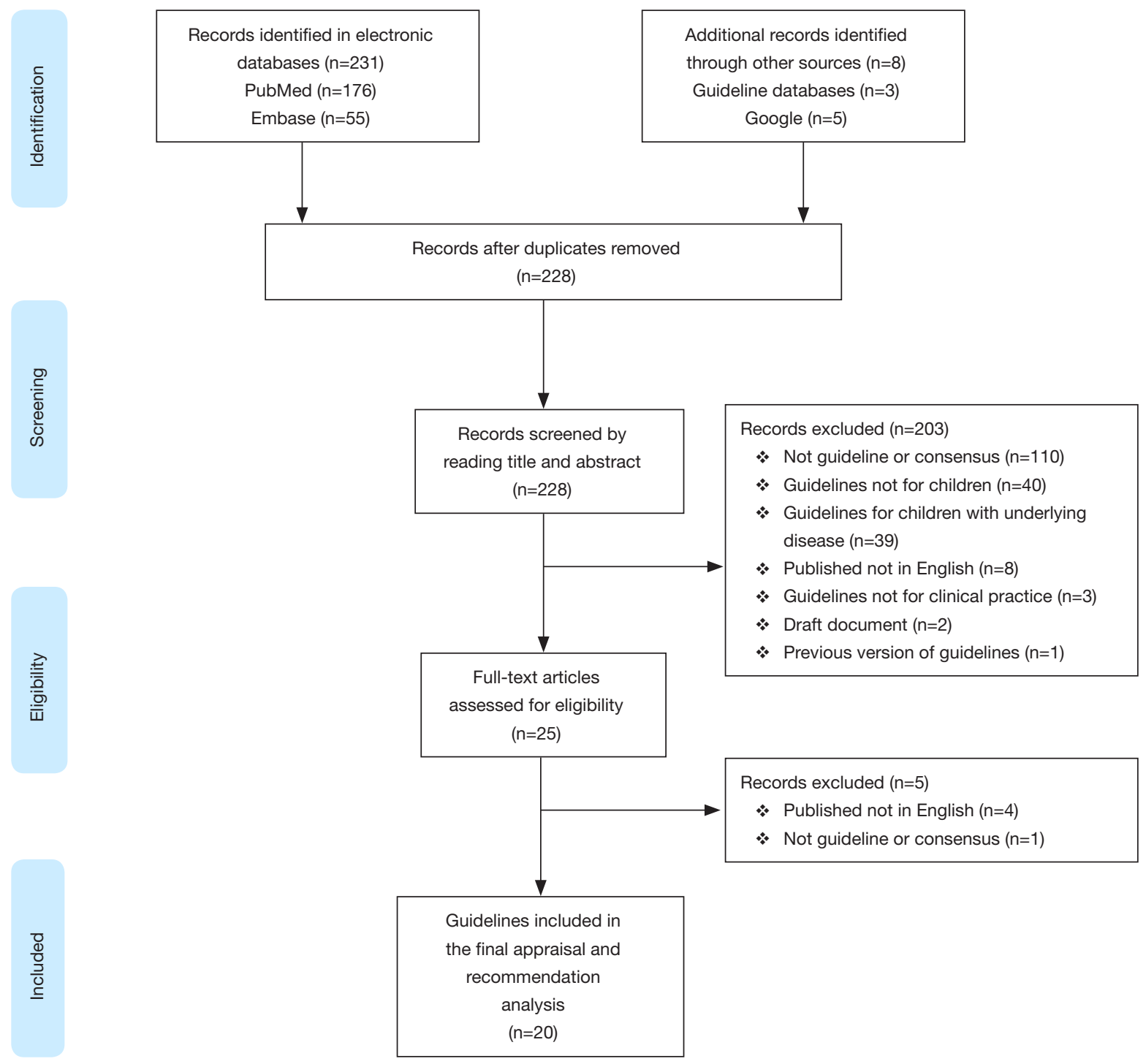

Figure 1 Flow diagram of the search and selection of the guidelines.

and 0.95 (95\% CI: 0.92-0.96) respectively, indicating high reliability between all reviewers. A total of 239 references were retrieved by the initial search. Twenty guidelines met our criteria were finally included (17-35). The process of guideline selection was illustrated in Figure 1. The characteristics of the included guidelines were presented in Table 1.

\section{The methodological and reporting quality of guidelines}

\section{Methodological quality}

The overall scores of AGREE II for each guideline were presented in Figure 2. The mean score of the included guidelines were $37 \%$ (range, $22-62 \%$ ). No guideline was classified as high quality, one guideline (5\%) developed by Children's Hospital of Chongqing Medical University was rated as moderate quality with a mean AGREE II score of $62 \%$, and $19(95 \%)$ were rated as low quality. Figure 3 presented the AGREE II scores of each domain. Domain 1 (scope and purpose) had the highest score (55\%) and domain 3 (rigor of development) had the lowest score (19\%). The AGREE II scores of guidelines that received funding, conducted systematic literature retrieval, and used the Grading of Recommendations Assessment, Development and Evaluation (GRADE) approach were significantly higher than those without funding, systematic 


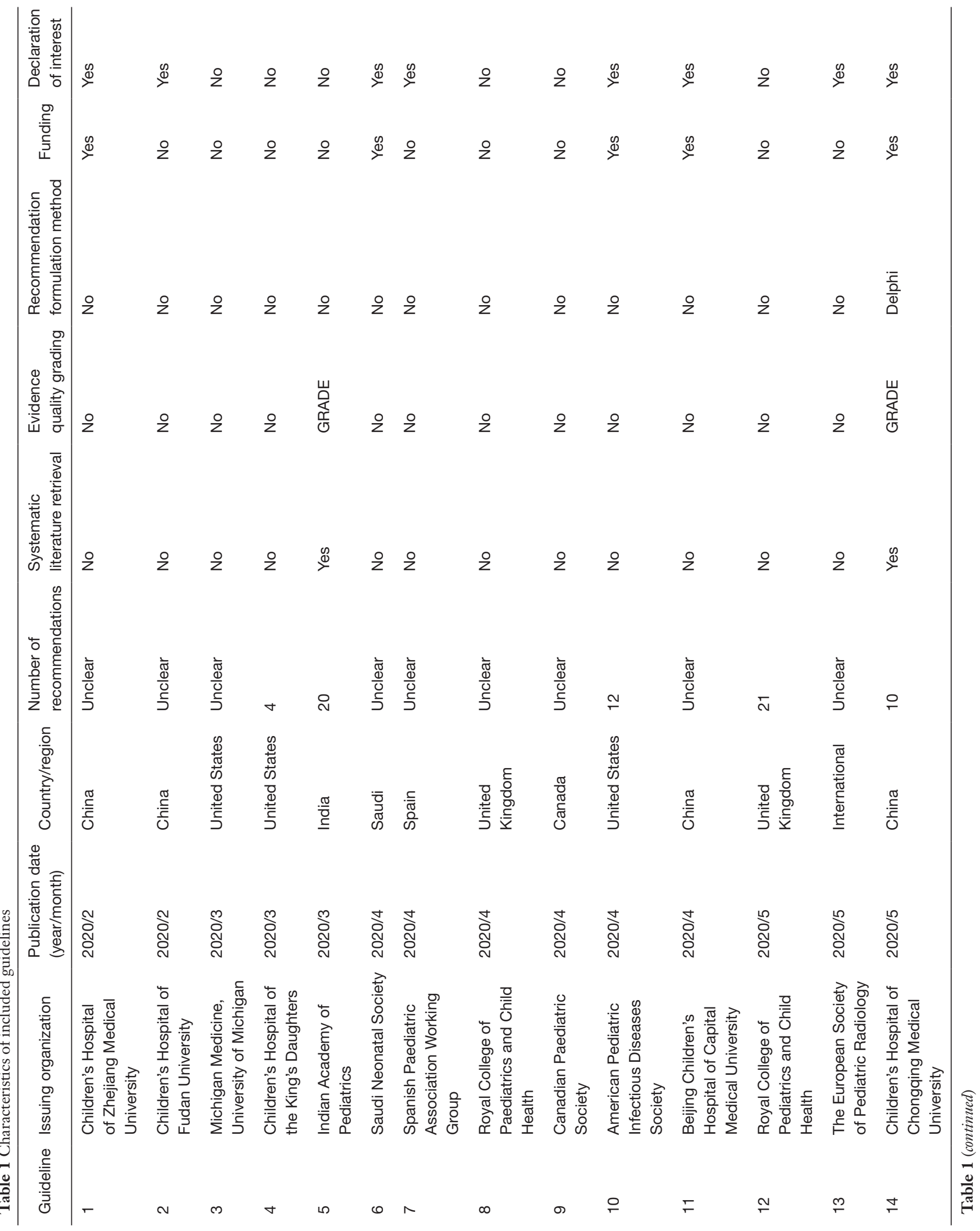




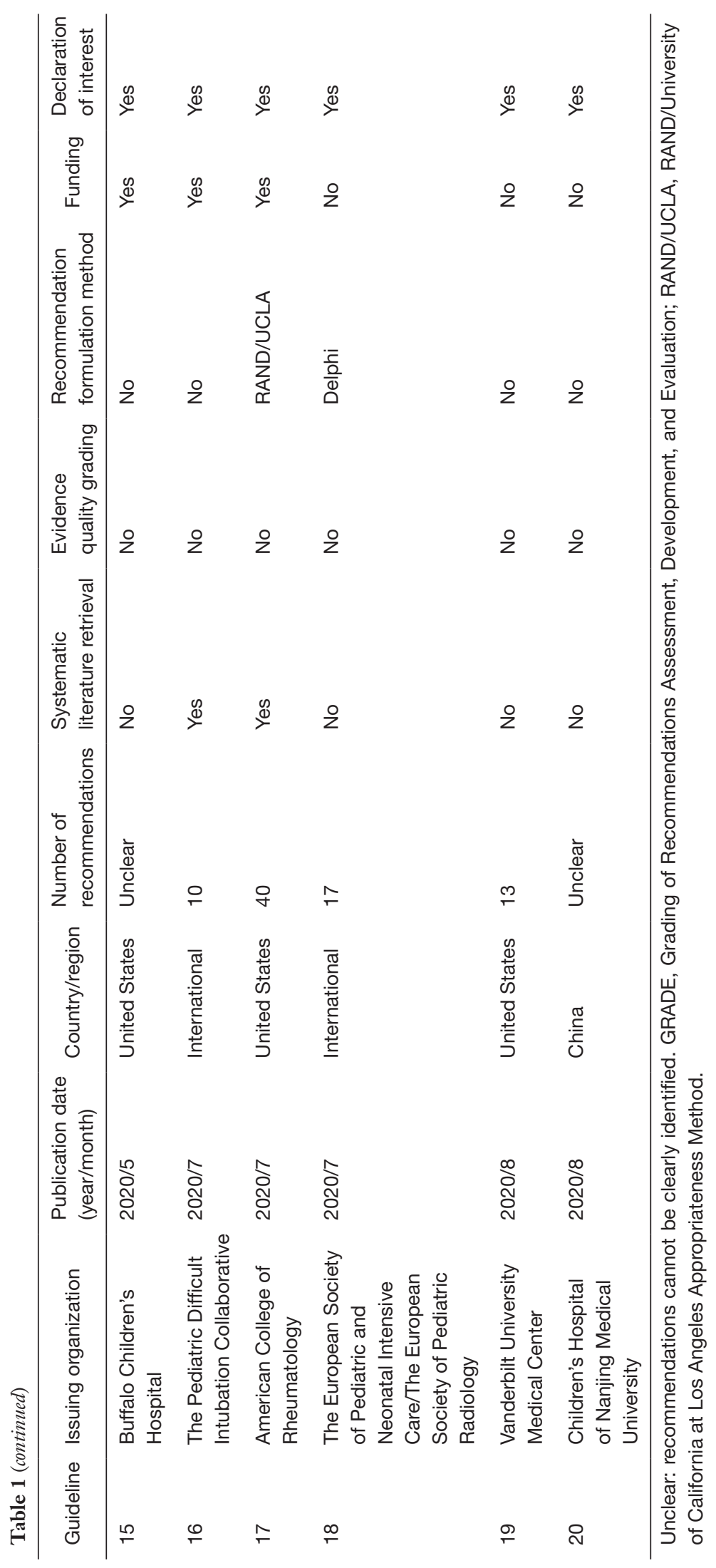




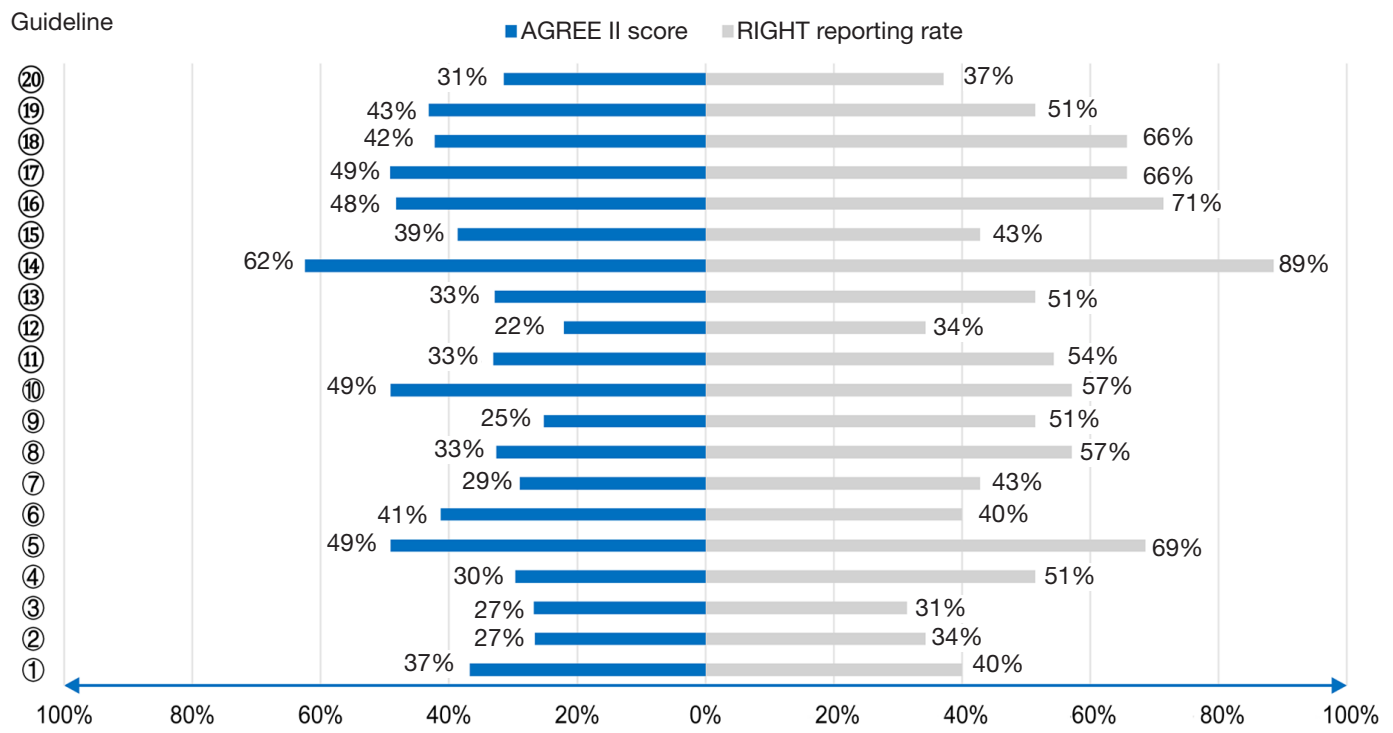

Figure 2 AGREE II mean scores and RIGHT reporting rate of each guideline. (1): Children's Hospital of Zhejiang Medical University; (2): Children's Hospital of Fudan University; (3): Michigan Medicine; University of Michigan; (4): Children's Hospital of the King's Daughters; (5): Indian Academy of Pediatrics; (6): Saudi Neonatal Society; 7): Spanish Paediatric Association Working Group; (8): Royal College of Paediatrics and Child Health; 9): Canadian Paediatric Society; 10: American Pediatric Infectious Diseases Society; 11): Beijing Children's Hospital of Capital Medical University; 12): Royal College of Paediatrics and Child Health; 13): The European Society of Paediatric Radiology; (14): Children's Hospital of Chongqing Medical University; 15): Buffalo Children's Hospital; 16: The Pediatric Difficult Intubation Collaborative; 17): American College of Rheumatology; 18): The European Society of Paediatric and Neonatal Intensive Care/The European Society of Paediatric Radiology; 19: Vanderbilt University Medical Center; 20: Children's Hospital of Nanjing Medical University. AGREE II, Appraisal of Guidelines for Research and Evaluation II; RIGHT, Reporting Items for practice Guidelines in HealThcare.

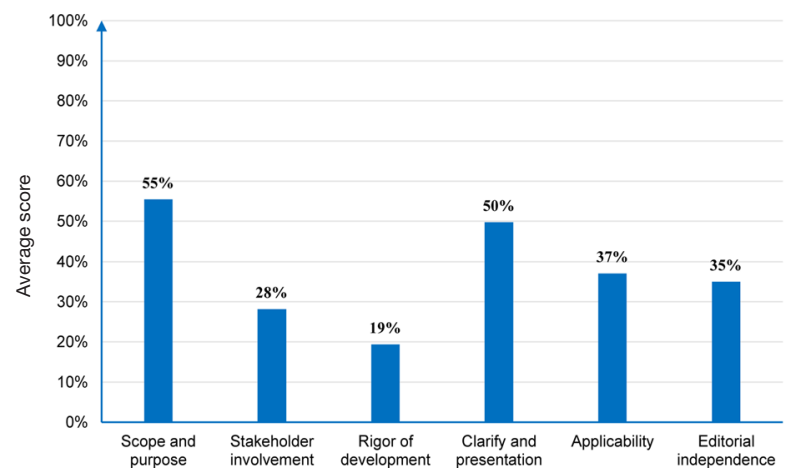

Figure 3 AGREE II mean scores of each domain for all included guidelines.

literature retrieval, and GRADE assessment $(\mathrm{P}<0.05)$. No statistical difference was found in AGREE II scores between guidelines with conflicts of interest (COI) and those without COI ( $\mathrm{P}=0.052)$ (Figure S1). The methodological quality of the included guidelines increased over time generally (Figure S2).

\section{Reporting quality}

The reporting rates of each guideline were presented in Figure 2. The mean reporting rate of the included guidelines was 52\% (range, 31-89\%). Only one guideline (5\%) developed by Children's Hospital of Chongqing Medical University was classified as high quality with a mean reporting rate of $89 \%, 12$ guidelines (60\%) were rated as moderate quality, and 7 guidelines (35\%) were rated as low quality. Figure S3 presented the reporting rate of each domain. Domain 2 (background) had the highest reporting rate $(66 \%)$, and domain 5 (review and quality assurance) had the lowest rate $(25 \%)$. The reporting rates of each item were shown in Figure 4. Among the key items (36), the reporting rates of item $11 \mathrm{~b}$ (systematic reviews identification and assessment) and item $18 \mathrm{~b}$ (role of funder) were $0 \%$, while the item $14 \mathrm{~b}$ (resource implication) and item 19a (COI) were $85 \%$ and $70 \%$, respectively. The reporting quality of guidelines that conducted systematic literature retrieval and used the GRADE approach was higher than those without systematic literature retrieval and GRADE assessment $(\mathrm{P}<0.05)(37)$. Funding $(\mathrm{P}=0.052)$ and 


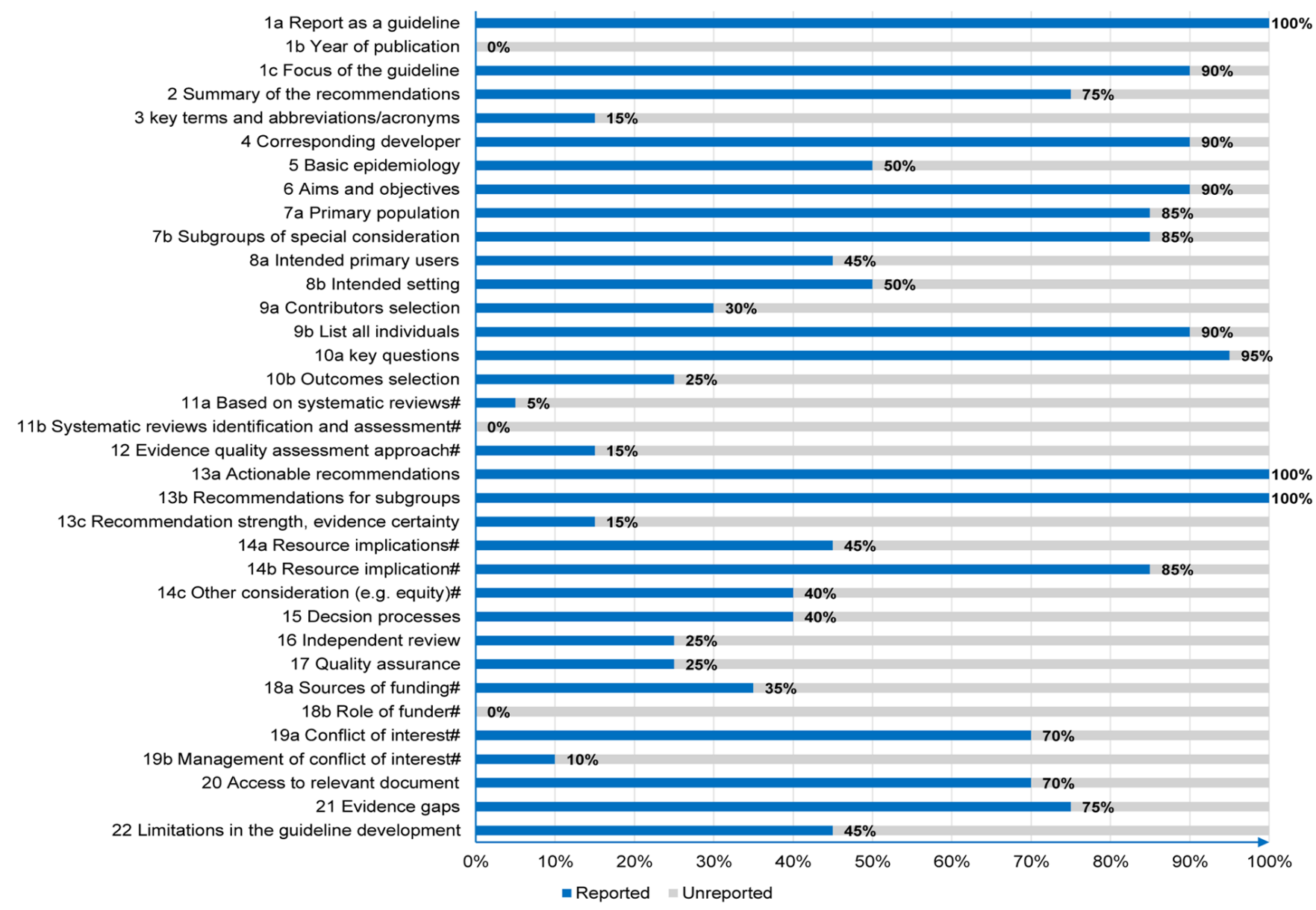

Figure 4 Percentage of reporting items in each item in the RIGHT checklist. \#, key items.

COI declaration $(P=0.165)$ had no impact on the reporting quality (Figure S4). The reporting quality of the included guidelines increased over time generally (Figure S2).

\section{Consistency of recommendations}

\section{Remdesivir}

Among 20 guidelines, five (25\%) guidelines recommended remdesivir for children with COVID-19 and nine (45\%) guidelines did not recommend the use of remdesivir (Figure 5). In the terms of the indication, two guidelines indicated remdesivir should only be used in critically ill patients. All guidelines did not report the timing of initiating remdesivir therapy. The summary of recommendations for the use of remdesivir was presented in Table S3. The supporting evidence regarding the use of remdesivir was very limited. No guidelines cited direct evidence from children with COVID-19. Two guidelines cited a case report from COVID-19 adult patients and one guideline cited a randomized controlled trial (RCT) from COVID-19 adult patients. The summary of supporting evidence for recommendations for remdesivir was shown in Table S4.

\section{Interferon}

Among 20 guidelines, three (15\%) guidelines recommended interferon for children with COVID-19, and 10 (50\%) guidelines did not recommend the use of interferon (Figure 5). As for indications of interferon, guidelines recommended interferon- $\alpha$ nebulization for acute respiratory infections in children with COVID-19. All guidelines did not report the timing of initiating interferon therapy. The summary of recommendations for the use of interferon was presented in Table S3. In terms of supporting 


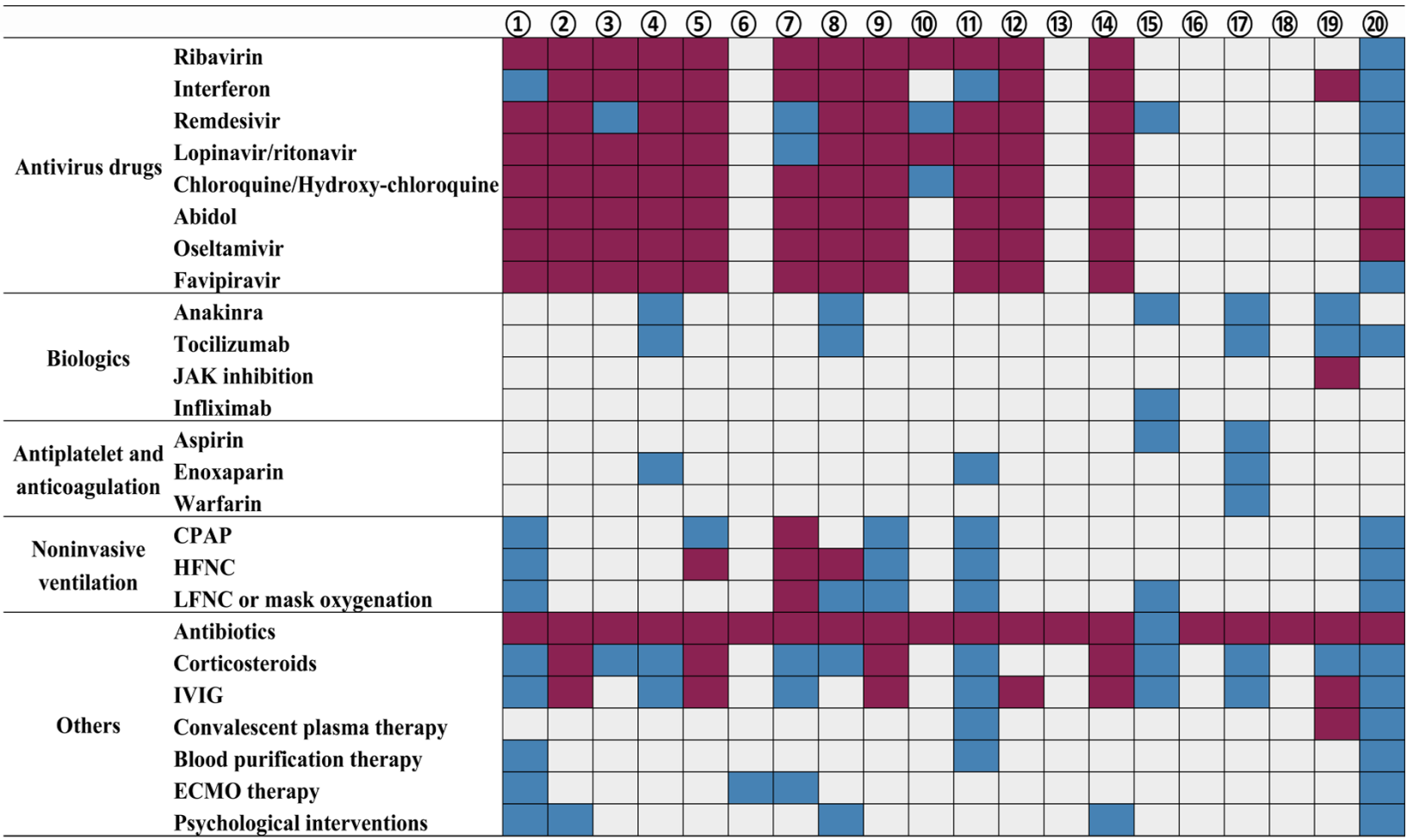

\begin{tabular}{|l|}
\hline Recommend \\
Not recommend \\
\hline Not report \\
\hline
\end{tabular}

Figure 5 Summary of key recommendations for the treatment of children with COVID-19. (1): Children's Hospital of Zhejiang Medical University; (2): Children's Hospital of Fudan University; (3): Michigan Medicine; University of Michigan; (4): Children's Hospital of the King's Daughters; (5): Indian Academy of Pediatrics; (6): Saudi Neonatal Society; (7): Spanish Paediatric Association Working Group; (8): Royal College of Paediatrics and Child Health; (9): Canadian Paediatric Society; 10: American Pediatric Infectious Diseases Society; 11): Beijing Children's Hospital of Capital Medical University; 12): Royal College of Paediatrics and Child Health; 13): The European Society of Paediatric Radiology; (14): Children's Hospital of Chongqing Medical University; (15): Buffalo Children's Hospital; 16): The Pediatric Difficult Intubation Collaborative; 17): American College of Rheumatology; 18): The European Society of Paediatric and Neonatal Intensive Care/The European Society of Paediatric Radiology; 19): Vanderbilt University Medical Center; (20): Children's Hospital of Nanjing Medical University. JAK, Janus-activated kinase; CPAP, continuous positive airway pressure; HFNC, high-flow nasal cannula; LFNC, low-flow nasal cannula; IVIG, intravenous immunoglobulin; ECMO, extracorporeal membrane oxygenation.

evidence, no guidelines cited direct evidence from children with COVID-19. Only one guideline cited evidence from adult patients with COVID-19, while the others cited indirect evidence from other diseases. The summary of supporting evidence for recommendations for interferon was shown in Table S5.

\section{Glucocorticoids}

Among 20 guidelines, 10 (50\%) guidelines recommended glucocorticoids for children with COVID-19 and four $(20 \%)$ guidelines did not recommend the use of glucocorticoids (Figure 5). As for the indication of glucocorticoids, guidelines recommended glucocorticoids only be used in severe or critical patients with acute respiratory distress syndrome (ARDS), septic shock, a multisystem inflammatory syndrome in children (MIS-C), and other serious complications. As for the usage of glucocorticoids, doses and types of glucocorticoids varied in different guidelines. All guidelines did not report the timing of initiating glucocorticoids therapy. The summary 
of recommendations for the use of glucocorticoids was presented in Table S6. The supporting evidence concerning the use of glucocorticoids in COVID-19 patients was rare. Only one guideline cited a cohort study from children with COVID-19. Three guidelines cited clinical studies from adults with COVID-19. The other guidelines cited indirect evidence from other diseases. The summary of supporting evidence for recommendations for glucocorticoid was shown in Table S7.

\section{IVIG}

Among 20 guidelines, seven (35\%) guidelines recommended IVIG for children with COVID-19 and six $(30 \%)$ guidelines did not recommend the use of IVIG (Figure 5). As for the indication of IVIG, four guidelines recommended it for severe or critical COVID-19 and three guidelines recommended it for MIS-C. In terms of dosing regimen, three guidelines recommended giving IVIG $1 \mathrm{~g} /$ $\mathrm{kg} /$ day for 2 days, or $400 \mathrm{mg} / \mathrm{kg} /$ day for 5 days for severe or critical COVID-19. Three guidelines recommended giving IVIG $1-2 \mathrm{~g} / \mathrm{kg}$ for MIS-C. All guidelines did not report the timing of initiating IVIG. The summary of recommendations for the use of IVIG was presented in Table S8. The supporting evidence concerning the use of IVIG in COVID-19 patients was also very limited. No direct evidence from children with COVID-19 was cited. Only two guidelines cited case reports from adults with COVID-19. The summary of supporting evidence for recommendations for IVIG was shown in Table S9.

\section{Biologics}

Three guidelines recommended anakinra and one guideline recommended infliximab for the treatment of MIS-C refractory to IVIG and glucocorticoids. Five guidelines recommended tocilizumab and two guidelines recommended anakinra for the treatment of severe or critical cases with evidence of hyperinflammation. The recommended dosing for tocilizumab is $12 \mathrm{mg} / \mathrm{kg}$ IV for children weighting $<30 \mathrm{~kg}$, and $8 \mathrm{mg} / \mathrm{kg}$ IV for children weighting $\geq 30 \mathrm{~kg}$ ( $\max$ dose $800 \mathrm{mg}$ ). The dosing regimen of anakinra varied across guidelines. None of the guidelines cited any supporting evidence from COVID-19 children. The summary of recommendations for the use of biologic was presented in Table S10.

\section{Antiplatelet and anticoagulation drugs}

There were significant differences in the indications and usages across different guidelines. Concerning the use of aspirin, one guideline recommended $80-100 \mathrm{mg} / \mathrm{kg} / \mathrm{day}$ for patients with excessive inflammation. The other guideline recommended 3-5 mg/ $\mathrm{kg} /$ day for MIS-C patients with CAA and a maximal Z-score $>2.5$ and/or thrombocytosis. As for the use of enoxaparin, one guideline recommended it for patients with increased D-dimer and at high risk of thrombosis. The other guideline recommended it for MIS-C patients with CAAs and a Z-score $\geq 10$. No specific dosing regimen for enoxaparin was provided. None of the guidelines cited any supporting evidence from COVID-19 children. The summary of recommendations for the use of antiplatelet and anticoagulation drugs was presented in Table S11.

\section{Other treatments}

Among the 20 guidelines, 19 (95\%) guidelines recommended against empirical use of antibiotics for children with COVID-19. Only one (5\%) guideline recommended the broad-spectrum antibiotics for patients with MIS-C. Six (30\%) guidelines recommended noninvasive ventilation for children with dyspnea at early stage, while one guideline (5\%) suggested an early intubation. Five $(25 \%)$ guidelines recommended psychotherapy for children with no specific measures provided. Convalescent plasma therapy, blood purification, and ECMO therapy were recommended for severe COVID-19 patients in two (10\%), three (15\%), and four (20\%) guidelines, respectively (Figure 5).

\section{Discussion}

Of the 20 guidelines included in this study, the overall methodological and reporting quality was not high. Recommendations varied greatly in the use of antiviral drugs, glucocorticoids, and IVIG. There was a lack of recommendations for the use of biologics, antiplatelet and anticoagulation drugs, non-invasive ventilation, psychotherapy, convalescent plasma therapy, blood purification, and ECMO therapy. Due to the lack of clinical trials for children with COVID-19, most guidelines did not cite direct evidence from children with COVID-19, but indirect evidence from adults with COVID-19 and other diseases.

The consistency of recommendations on the use of remdesivir was generally low. Five guidelines recommended remdesivir. Their reasons were as follows. Remdesivir can effectively inhibit SARS-CoV-2 in vitro (38). Besides, adult patients treated with remdesivir showed improvement in symptoms and level of respiratory support (39). Nine 
guidelines did not recommend remdesivir. They indicated that no clinical studies have investigated its efficacy on children with COVID-19. Further, the efficacy of remdesivir for adults with COVID-19 remained uncertain $(40,41)$. The efficacy of remdesivir may depend on the timing of its use. Some clinical trials found remdesivir was effective when administered in the first 5 days of symptoms, when the viral load was high $(39,40)$. It may have low efficacy when it is prescribed in advanced stage, with low viral load. More clinical studies are needed to investigate the proper time of remdesivir use and its efficacy for children with COVID-19.

Recommendations were inconsistent in the use of interferon for children with COVID-19. Three guidelines recommended the use of interferon and their reason was that interferon- $\alpha$ can reduce viral load. However, none of the guidelines cited any evidence from COVID-19 patients. Nine guidelines recommended against the use of interferon and their reasons were the following. First, no clinical studies demonstrated that interferon was effective in treating children with COVID-19. Moreover, the efficacy of interferon in treatment of adult with COVID-19 was unclear. Although several RCTs with small sample size showed interferon beta was effective in treatment of adults with COVID-19 (42,43), a living systematic review and network meta-analysis showed it had no effects (44). Second, therapy with interferon was associated with a variety of adverse effects, including fatigue, anorexia, nausea, diarrhea, depression, neutropenia, and anemia $(45,46)$. Given the above concerns, interferon may not be used for treating children with COVID-19.

Recommendations on the use of glucocorticoids varied across guidelines. Four guidelines did not recommend the use of glucocorticoids. Their reasons were that evidence showed that systemic glucocorticoids may have no benefit in severe cases of SARS-CoV-2 and SARS infection (47). Besides severe side effects such as femoral head necrosis and immunosuppression may occur after high dose administrations (48). Ten guidelines recommended the use of glucocorticoids and their reasons were as follows. First, a meta-analysis demonstrated the benefits of glucocorticoids in moderate or severe adult patients with COVID-19 (49), and WHO recommended systemic corticosteroids rather than no systemic corticosteroids for the treatment of patients with severe and critical COVID-19 (50). Second, in settings where monoclonal antibody shortages, glucocorticoids may be the only option for immunomodulatory therapy for critical cases. Third, the cost of glucocorticoids was cheap. Whether glucocorticoids can be used for children with COVID-19 remains unclear. High-quality clinical studies are required to explore the efficacy, safety, dosing, and timing of glucocorticoids therapy for children with COVID-19.

After the emerge of MIS-C, IVIG is the most commonly used immunomodulatory medications in MIS-C patients (51). Some guidelines recommended IVIG for treatment of MIS-C. However, their supporting evidence was mainly based on IVIG use in KD and fulminant myocarditis, two conditions that resembled MIS-C in some aspects $(52,53)$. Although recent case reports found MIS-C patients receiving IVIG resolved rapidly, improvement in clinical status was also observed in mild cases without IVIG treatment $(51,54)$. Data on the efficacy of IVIG to treat MIS-C and indications for the use of IVIG is still limited. And there is few study to compare the efficacy of IVIG and glucocorticoids in MIS-C or to determine if these treatments should be provided alone or in combination. Therefore, more high-quality clinical trials are needed to explore the above problems.

Biological agents may be promising treatments for COVID-19 patients with high inflammatory response syndrome $(55,56)$. A RCT found tocilizumab may reduce the likelihood of mechanical ventilation or death in adult patients with COVID-19 (55). Targeting the inflammatory cascade with anakinra in moderate to severe COVID-19 adults showed good clinical outcomes (56). The included guidelines suggested biologics could be used for pediatric COVID-19. However, recent living systematic reviews and network meta-analyses found tocilizumab did not reduce short-term mortality $(44,57)$. Moreover, there is little evidence from pediatric COVID-19 to support the use of biological agents. Therefore, more clinical studies are needed to investigate the therapeutic effects of biologics on COVID-19 children with high inflammatory response, especially severe and refractory MIS-C.

The advantages of this study were as follows. First, we summarized all key recommendations and compared and visualized the inconsistencies among guidelines related to children with COVID-19. Our findings may provide objective guidance for pediatricians selecting the appropriate treatment. Second, we performed a systematic literature search, and comprehensively explored both methodological and reporting quality of the guidelines. Our findings provided an informative overview of guideline quality for methodologists and may contribute to future guideline development and updates. Third, this 
is to our knowledge the first study that comprehensively evaluated the supporting evidence. We proposed the existing research gaps, providing a reference for medical researchers to conduct clinical trials in the future. However, our study had some limitations. First, we restricted our search to guidelines published in English and excluded the guidelines in other languages. Second, we only analyzed recommendations regarding treatment, and recommendations concerning diagnosis, isolation, and prevention were not evaluated. Third, we did not include guidelines after September 2020. Therefore, we were unable to analyze the guidelines published after that time.

\section{Conclusions}

The methodological and reporting quality of guidelines for treating children with COVID-19 was not high. There was a wide discrepancy between the guidelines in recommendations on the use of antiviral drugs, glucocorticoids, and IVIG. Clinical researches on the pediatric COVID-19 treatment were rare. High-quality guidelines and clinical studies are warranted to improve the treatment of children with COVID-19.

\section{Acknowledgments}

Funding: This work was supported by grants from National Clinical Research Center for Child Health and Disorders (Children's Hospital of Chongqing Medical University, Chongqing, China) (NCRCCHD-2020-EP-01), Special Fund for Key Research and Development Projects in Gansu Province in 2020, The Fourth Batch of "Special Project of Science and Technology for Emergency Response to COVID-19" of Chongqing Science and Technology Bureau, Special funding for Prevention and Control of Emergency of COVID-19 from Key Laboratory of Evidence Based Medicine and Knowledge Translation of Gansu Province (grant number GSEBMKT-2020YJ01), the Fundamental Research Funds for the Central Universities (grant number lzujbky-2020-sp14), Research on Response to the Coronavirus Disease 2019 Outbreak in Gansu Province (grant number 20ZD016), Research on Response to the Coronavirus Disease 2019 Outbreak in Gansu Province (grant number 20ZD016), the National Key R\&D Program of China (2018YFC1705500), the National Key R\&D Program of China (2019YFC1712000), and the 2020 Key R\&D project of Gansu Province (20YF2FA027).

\section{Footnote}

Reporting Checklist: The authors have completed the PRISMA reporting checklist. Available at http://dx.doi. org/10.21037/atm-20-7000

Data Sharing Statement: Available at http://dx.doi. org/10.21037/atm-20-7000

Peer Review File: Available at http://dx.doi.org/10.21037/ atm-20-7000

Conflicts of Interest: All authors have completed the ICMJE uniform disclosure form (available at http://dx.doi. org/10.21037/atm-20-7000). QZ, EL, ZF, YC, and ZL were the authors of Rapid advice guidelines for management of children with COVID-19. QL, QS, and ZW participated in the development of Rapid advice guidelines for management of children with COVID-19. The other authors have no conflicts of interest to declare.

Etbical Statement: The authors are accountable for all aspects of the work in ensuring that questions related to the accuracy or integrity of any part of the work are appropriately investigated and resolved

Open Access Statement: This is an Open Access article distributed in accordance with the Creative Commons Attribution-NonCommercial-NoDerivs 4.0 International License (CC BY-NC-ND 4.0), which permits the noncommercial replication and distribution of the article with the strict proviso that no changes or edits are made and the original work is properly cited (including links to both the formal publication through the relevant DOI and the license). See: https://creativecommons.org/licenses/by-nc-nd/4.0/.

\section{References}

1. Dong E, Du H, Gardner L. An interactive web-based dashboard to track COVID-19 in real time. Lancet Infect Dis 2020;20:533-4.

2. World Health Organization. WHO Coronavirus Disease (COVID-19) Dashboard. Available online: https://covid19. who.int/

3. Ludvigsson JF. Systematic review of COVID-19 in children shows milder cases and a better prognosis than adults. Acta Paediatr 2020;109:1088-95.

4. Dong Y, Mo X, Hu Y, et al. Epidemiology of COVID-19 
Among Children in China. Pediatrics 2020;145:e20200702.

5. Feldstein LR, Rose EB, Horwitz SM, et al. Multisystem Inflammatory Syndrome in U.S. Children and Adolescents. N Engl J Med 2020;383:334-46.

6. Sanders JM, Monogue ML, Jodlowski TZ, et al. Pharmacologic Treatments for Coronavirus Disease 2019 (COVID-19): A Review. JAMA 2020;323:1824-36.

7. Woolf SH, Grol R, Hutchinson A, et al. Clinical guidelines: potential benefits, limitations, and harms of clinical guidelines. BMJ 1999;318:527-30.

8. Moher D, Liberati A, Tetzlaff J, et al. Preferred reporting items for systematic reviews and meta-analyses: the PRISMA statement. PLoS Med 2009;6:e1000097.

9. Li L, Tian J, Tian H, et al. Network meta-analyses could be improved by searching more sources and by involving a librarian. J Clin Epidemiol 2014;67:1001-7.

10. Brouwers MC, Kho ME, Browman GP, et al. AGREE II: advancing guideline development, reporting and evaluation in health care. CMAJ 2010;182:E839-42.

11. Simancas-Racines D, Montero-Oleas N, Vernooij RWM, et al. Quality of clinical practice guidelines about red blood cell transfusion. J Evid Based Med 2019;12:113-24.

12. Ghanbari A, Rahmatpour P, Jafaraghaee F, et al. Quality assessment of diabetic foot ulcer clinical practice guidelines. J Evid Based Med 2018;11:200-7.

13. Wu D, Jiang W, Yu L, et al. Quality assessment of clinical practice guidelines for infectious diseases in China. J Evid Based Med 2018;11:95-100.

14. Maes-Carballo M, Mignini L, Martín-Díaz M, et al. Quality and reporting of clinical guidelines for breast cancer treatment: A systematic review. Breast 2020;53:201-11.

15. Chen Y, Yang K, Marušic A, et al. A Reporting Tool for Practice Guidelines in Health Care: The RIGHT Statement. Ann Intern Med 2017;166:128-32.

16. Lin I, Wiles LK, Waller R, et al. Poor overall quality of clinical practice guidelines for musculoskeletal pain: a systematic review. Br J Sports Med 2018;52:337-43.

17. Chen ZM, Fu jf, Shu Q, et al. Diagnosis and treatment recommendations for pediatric respiratory infection caused by the 2019 novel coronavirus. World J Pediatr 2020;16:240-6.

18. Wang L, Shi Y, Xiao T, et al. Chinese expert consensus on the perinatal and neonatal management for the prevention and control of the 2019 novel coronavirus infection (First edition). Ann Transl Med 2020;8:47.

19. Michigan Medicine, University of Michigan. Inpatient guidance for treatment of COVID-19 in adults and children. Available online: https://www.med.umich.edu/ asp/pdf/adult_guidelines/COVID-19-treatment.pdf

20. Children's Hospital of the King's Daughters. CHKD Treatment Guideline for COVID-19 in Children. Available online: https://www.chkd.org/Patients-andFamilies/COVID-19/

21. Chawla D, Chirla D, Dalwai S, et al. Perinatal-Neonatal Management of COVID-19 Infection - Guidelines of the Federation of Obstetric and Gynaecological Societies of India (FOGSI), National Neonatology Forum of India (NNF), and Indian Academy of Pediatrics (IAP). Indian Pediatr 2020;57:536-48.

22. Almudeer A, Alallah J, AlSaedi S, et al. Recommendations for the management of newborn with suspected or confirmed coronavirus disease-19. J Clin Neonatol 2020;9:93-7.

23. Calvo C, López-Hortelano MG, Vicente JCC, et al. Recommendations on the clinical management of the COVID-19 infection by the «new coronavirus» SARSCoV2. Spanish Paediatric Association working group. An Pediatr (Engl Ed) 2020;92:241.e1-11.

24. Royal College of Pediatrics and Child Health. COVID-19 - clinical management of children admitted to hospital with suspected COVID-19. Available online: https://www. rcpch.ac.uk/resources/covid-19-clinical-managementchildren-admitted-hospital-suspected-covid-19

25. Canadian Paediatric Society. The acute management of paediatric coronavirus disease 2019 (COVID-19). Available online: https://www.cps.ca/en/documents/position/theacute-management-of-paediatric-coronavirus-disease2019covid-19

26. Chiotos K, Hayes M, Kimberlin DW, et al. Multicenter initial guidance on use of antivirals for children with COVID-19/SARS-CoV-2. J Pediatric Infect Dis Soc 2020;9:701-15.

27. Shen K, Yang Y, Jiang R, et al. Updated diagnosis, treatment and prevention of COVID-19 in children: experts' consensus statement (condensed version of the second edition). World J Pediatr 2020;16:232-9.

28. Royal College of Pediatrics and Child Health. Guidance: Paediatric multisystem inflammatory syndrome temporally associated with COVID-19. Available online: https://www.rcpch.ac.uk/resources/guidance-paediatricmultisystem-inflammatory-syndrome-temporallyassociated-covid-19-pims

29. Raissaki M, Shelmerdine SC, Damasio MB, et al. Management strategies for children with COVID-19: ESPR practical recommendations. Pediatr Radiol 
2020;50:1313-23.

30. Liu E, Smyth RL, Luo Z, et al. Rapid advice guidelines for management of children with COVID-19. Ann Transl Med 2020;8:617.

31. Hennon TR, Penque MD, Abdul-Aziz R, et al. COVID-19 associated Multisystem Inflammatory Syndrome in Children (MIS-C) guidelines; a Western New York approach. Prog Pediatr Cardiol 2020. [Epub ahead of print]. doi: 10.1016/j.ppedcard.2020.101232.

32. Matava CT, Kovatsis PG, Lee JK, et al. Pediatric Airway Management in COVID-19 Patients: Consensus Guidelines From the Society for Pediatric Anesthesia's Pediatric Difficult Intubation Collaborative and the Canadian Pediatric Anesthesia Society. Anesth Analg 2020;131:61-73.

33. Terheggen U, Heiring C, Kjellberg M, et al. European consensus recommendations for neonatal and paediatric retrievals of positive or suspected COVID-19 patients. Pediatr Res 2020. [Epub ahead of print]. doi: 10.1038/ s41390-020-1050-z.

34. Dulek DE, Fuhlbrigge RC, Tribble AC, et al. Multidisciplinary Guidance Regarding the Use of Immunomodulatory Therapies for Acute COVID-19 in Pediatric Patients. J Pediatric Infect Dis Soc 2020;9:716-37.

35. Miao H, Li H, Yao Y, et al. Update on recommendations for the diagnosis and treatment of SARS-CoV-2 infection in children. Eur J Clin Microbiol Infect Dis 2020;39:2211-23.

36. Wang X, Zhou Q, Chen Y, et al. Using RIGHT (Reporting Items for Practice Guidelines in Healthcare) to evaluate the reporting quality of WHO guidelines. Health Res Policy Syst 2020;18:75.

37. Norris SL, Meerpohl JJ, Akl EA, et al. The skills and experience of GRADE methodologists can be assessed with a simple tool. J Clin Epidemiol 2016;79:150-8.e1.

38. Wang M, Cao R, Zhang L, et al. Remdesivir and chloroquine effectively inhibit the recently emerged novel coronavirus (2019-nCoV) in vitro. Cell Res 2020;30:269-71.

39. Grein J, Ohmagari N, Shin D, et al. Compassionate Use of Remdesivir for Patients with Severe Covid-19. N Engl J Med 2020;382:2327-36.

40. Goldman JD, Lye DCB, Hui DS, et al. Remdesivir for 5 or 10 Days in Patients with Severe Covid-19. N Engl J Med 2020;383:1827-37.

41. Spinner CD, Gottlieb RL, Criner GJ, et al. Effect of Remdesivir vs Standard Care on Clinical Status at 11 Days in Patients With Moderate COVID-19: A Randomized Clinical Trial. JAMA 2020;324:1048-57.

42. Rahmani H, Davoudi-Monfared E, Nourian A, et al. Interferon beta-1b in treatment of severe COVID-19: A randomized clinical trial. Int Immunopharmacol 2020;88:106903.

43. Monk PD, Marsden RJ, Tear VJ, et al. Safety and efficacy of inhaled nebulised interferon beta-1a (SNG001) for treatment of SARS-CoV-2 infection: a randomised, double-blind, placebo-controlled, phase 2 trial. Lancet Respir Med 2021;9:196-206.

44. Siemieniuk RA, Bartoszko JJ, Ge L, et al. Drug treatments for covid-19: living systematic review and network metaanalysis. BMJ 2020;370:m2980.

45. Muir AJ, Arora S, Everson G, et al. A randomized phase $2 \mathrm{~b}$ study of peginterferon lambda-1a for the treatment of chronic HCV infection. J Hepatol 2014;61:1238-46.

46. Raison CL, Demetrashvili M, Capuron L, et al. Neuropsychiatric adverse effects of interferonalpha: recognition and management. CNS Drugs 2005;19:105-23.

47. Lu S, Zhou Q, Huang L, et al. Effectiveness and safety of glucocorticoids to treat COVID-19: a rapid review and meta-analysis. Ann Transl Med 2020;8:627.

48. Lansbury LE, Rodrigo C, Leonardi-Bee J, et al. Corticosteroids as Adjunctive Therapy in the Treatment of Influenza: An Updated Cochrane Systematic Review and Meta-analysis. Crit Care Med 2020;48:e98-106.

49. WHO Rapid Evidence Appraisal for COVID-19 Therapies (REACT) Working Group, Sterne JA, Murthy $\mathrm{S}$, et al. Association Between Administration of Systemic Corticosteroids and Mortality Among Critically Ill Patients With COVID-19: A Meta-analysis. JAMA 2020;324:1330-41.

50. Siemieniuk R, Rochwerg B, Agoritsas T, et al. A living WHO guideline on drugs for covid-19. BMJ 2020;370:m3379.

51. Lee PY, Day-Lewis M, Henderson LA, et al. Distinct clinical and immunological features of SARS-CoV-2induced multisystem inflammatory syndrome in children. J Clin Invest 2020;130:5942-50.

52. Kobayashi T, Saji T, Otani T, et al. Efficacy of immunoglobulin plus prednisolone for prevention of coronary artery abnormalities in severe Kawasaki disease (RAISE study): a randomised, open-label, blindedendpoints trial. Lancet 2012;379:1613-20.

53. Furusho K, Kamiya T, Nakano H, et al. High-dose intravenous gammaglobulin for Kawasaki disease. Lancet 
1984;2:1055-8.

54. Gruber CN, Patel RS, Trachtman R, et al. Mapping Systemic Inflammation and Antibody Responses in Multisystem Inflammatory Syndrome in Children (MIS-C). Cell 2020;183:982-95.e14.

55. Salama C, Han J, Yau L, et al. Tocilizumab in Patients Hospitalized with Covid-19 Pneumonia. N Engl J Med 2021;384:20-30.

Cite this article as: Li Q, Zhou Q, Xun Y, Liu H, Shi Q, Wang Z, Zhao S, Liu X, Liu E, Fu Z, Chen Y, Luo Z. Quality and consistency of clinical practice guidelines for treating children with COVID-19. Ann Transl Med 2021;9(8):633. doi: 10.21037/atm-20-7000
56. Aouba A, Baldolli A, Geffray L, et al. Targeting the inflammatory cascade with anakinra in moderate to severe COVID-19 pneumonia: case series. Ann Rheum Dis 2020;79:1381-2.

57. Tleyjeh IM, Kashour Z, Damlaj M, et al. Efficacy and safety of tocilizumab in COVID-19 patients: a living systematic review and meta-analysis. Clin Microbiol Infect 2021;27:215-27. 


\section{Appendix 1 Search strategy}

\section{Search in Medline}

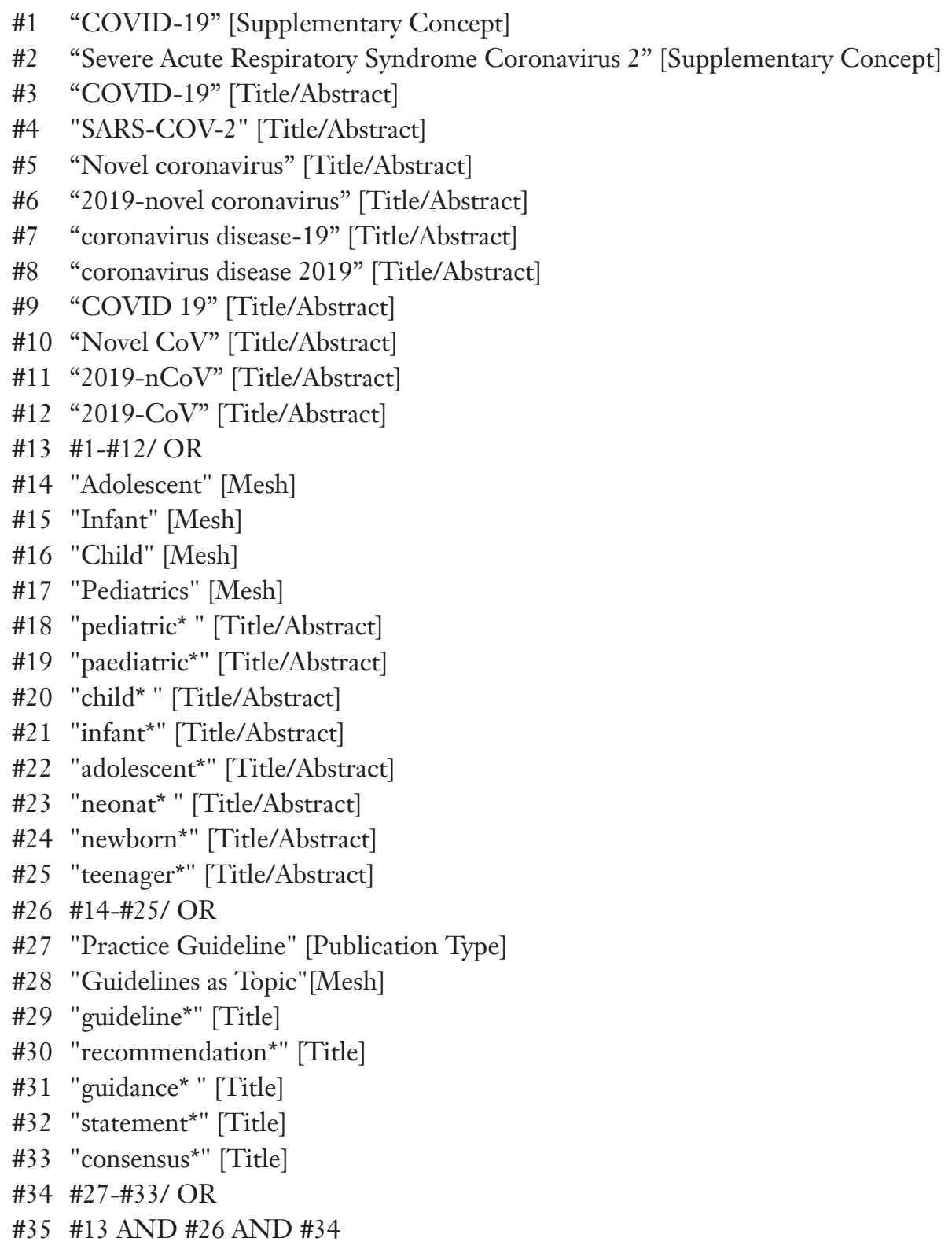

\section{Search in Embase}

\#1 'coronavirus disease 2019'/exp

\#2 'severe acute respiratory syndrome coronavirus 2'/exp

\#3 'COVID-19': ab,ti

\#4 'SARS-COV-2': ab,ti

\#5 'novel coronavirus': ab,ti

\#6 '2019-novel coronavirus': ab,ti

\#7 'coronavirus disease-19': ab,ti 
\#8 'coronavirus disease 2019': ab,ti

\#9 'COVID 19': ab,ti

\#10 'novel cov': ab,ti

\#11 '2019-ncov': ab,ti

\#12 '2019-cov': ab,ti

\#13 \#1-\#12/ OR

$\# 14$ 'child'/exp

\#15 'child*': ab,ti

\#16 'pediatric*': ab,ti

\#17 'paediatric*': ab,ti

\#18 'adolescent"': ab,ti

\#19 'infant*': ab,ti

\#20 'neonat ${ }^{* '}: a b, t i$

\#21 'newborn*': ab,ti

\#22 'teenager*': ab,ti

\#23 \#14-\#22/ OR

\#24 'practice guideline'/exp

\#25 'guideline*':ti

\#26 'recommendation*':ti

\#27 'guidance*':ti

\#28 'statement ${ }^{* \prime}:$ ti

\#29 ' consensus*':ti

\#30 \#24-\#29/ OR

\#31 \#13 AND \#23 AND \#30

\#32 [medline]/lim in \#31

\#33 \#31 NOT \#32

\section{Search in guideline databases}

\section{Website links}

Guidelines International Network (G-I-N): www.g-i-n.net

National Institute for Health and Clinical Excellence (NICE): www.nice.org.uk

Scottish Intercollegiate Guidelines Network (SIGN): www.sign.ac.uk/our-guidelines.html

World Health Organization (WHO): https://www.who.int/emergencies/diseases/novel-coronavirus-2019

COVID-19 page on the International Pediatric Association website: https://ipa-world.org/covid-19-news-and-updates. php

European Centres for Disease Control: https://www.ecdc.europa.eu/en/coronavirus

US Centers for Disease Control and Prevention: https://www.cdc.gov/coronavirus/2019-nCoV/index.html

Canadian Paediatric Society: https://www.cps.ca/en/tools-outils/covid-19-information-and-resources-for-paediatricians

American Academy of Paediatrics: https://services.aap.org/en/pages/2019-novel-coronavirus-covid-19-infections

Indian Academy of Paediatrics: www.iapindia.org

UK Royal College of Paediatrics and Child Health guidance for paediatric services: https://www.rcpch.ac.uk/key-topics/ covid-19

\section{Search strategy}

Combinations of the following key words were searched: 'COVID-19','child','guideline'.

\section{Search in Google website}

A search was conducted via the Google engine using the following terms: 'COVID-19'AND 'child'AND '(guideline or guidance or consensus or recommendation)' in English. We screened the first 100 records. 
Table S1 AGREE II scores for each item in each guideline

\begin{tabular}{|c|c|c|c|c|c|c|c|c|c|c|c|c|c|c|c|c|c|c|c|c|c|c|}
\hline Guideline & & & 1 & 2 & 3 & 4 & 5 & 6 & 7 & 8 & 9 & 10 & 11 & 12 & 13 & 14 & 15 & 16 & 17 & 18 & 19 & 20 \\
\hline \multirow{4}{*}{ Domain1 } & & Appraiser2 & 5 & 5 & 4 & 4 & 5 & 6 & 5 & 5 & 5 & 5 & 5 & 4 & 5 & 6 & 4 & 5 & 5 & 6 & 5 & 5 \\
\hline & Item2 & Appraiser1 & 3 & 4 & 3 & 3 & 3 & 3 & 3 & 4 & 3 & 4 & 3 & 3 & 4 & 5 & 3 & 5 & 5 & 5 & 5 & 5 \\
\hline & & Appraiser2 & 4 & 5 & 3 & 3 & 5 & 4 & 3 & 4 & 3 & 5 & 4 & 3 & 4 & 6 & 4 & 5 & 4 & 5 & 5 & 5 \\
\hline & & Appraiser2 & 5 & 4 & 5 & 4 & 3 & 4 & 3 & 5 & 4 & 4 & 5 & 4 & 2 & 5 & 4 & 5 & 3 & 5 & 5 & 4 \\
\hline \multirow[t]{4}{*}{ Domain2 } & Item4 & Appraiser1 & 3 & 3 & 1 & 2 & 6 & 4 & 5 & 2 & 2 & 4 & 4 & 2 & 4 & 4 & 4 & 4 & 5 & 5 & 4 & 4 \\
\hline & & Appraiser2 & 2 & 2 & 1 & 3 & 5 & 5 & 5 & 2 & 3 & 5 & 5 & 2 & 5 & 4 & 4 & 4 & 5 & 6 & 4 & 4 \\
\hline & Item5 & Appraiser1 & 1 & 1 & 1 & 1 & 6 & 1 & 1 & 1 & 1 & 1 & 1 & 1 & 1 & 4 & 1 & 1 & 1 & 1 & 1 & 1 \\
\hline & & Appraiser2 & 2 & 2 & 3 & 4 & 4 & 4 & 2 & 4 & 4 & 3 & 4 & 4 & 2 & 5 & 3 & 1 & 3 & 4 & 4 & 1 \\
\hline \multirow[t]{12}{*}{ Domain3 } & Item7 & Appraiser1 & 1 & 2 & 1 & 1 & 6 & 1 & 1 & 1 & 1 & 1 & 1 & 1 & 1 & 6 & 1 & 5 & 3 & 1 & 2 & 1 \\
\hline & & Appraiser2 & 1 & 2 & 1 & 1 & 5 & 1 & 1 & 1 & 1 & 1 & 1 & 1 & 1 & 6 & 1 & 6 & 3 & 1 & 2 & 1 \\
\hline & Item8 & Appraiser1 & 1 & 1 & 1 & 1 & 2 & 1 & 1 & 1 & 1 & 1 & 1 & 1 & 1 & 6 & 1 & 2 & 1 & 1 & 1 & 1 \\
\hline & & Appraiser2 & 1 & 1 & 1 & 1 & 2 & 1 & 1 & 1 & 1 & 2 & 1 & 1 & 1 & 6 & 1 & 4 & 1 & 1 & 1 & 1 \\
\hline & Item9 & Appraiser1 & 1 & 1 & 1 & 1 & 6 & 1 & 1 & 1 & 1 & 4 & 1 & 1 & 1 & 6 & 1 & 1 & 1 & 1 & 1 & 1 \\
\hline & & Appraiser2 & 1 & 1 & 1 & 1 & 5 & 1 & 1 & 1 & 1 & 5 & 1 & 1 & 1 & 5 & 1 & 1 & 1 & 1 & 1 & 1 \\
\hline & Item10 & Appraiser1 & 1 & 1 & 1 & 1 & 1 & 1 & 1 & 1 & 1 & 4 & 1 & 1 & 1 & 6 & 1 & 2 & 6 & 7 & 2 & 1 \\
\hline & & Appraiser2 & 2 & 2 & 3 & 4 & 4 & 3 & 3 & 5 & 2 & 5 & 2 & 1 & 4 & 6 & 2 & 5 & 4 & 5 & 6 & 2 \\
\hline & Item13 & Appraiser1 & 1 & 1 & 1 & 1 & 1 & 1 & 1 & 1 & 1 & 1 & 1 & 1 & 1 & 2 & 1 & 1 & 1 & 1 & 1 & 1 \\
\hline & & Appraiser2 & 1 & 1 & 1 & 1 & 1 & 1 & 1 & 1 & 1 & 1 & 1 & 1 & 1 & 3 & 1 & 1 & 1 & 1 & 1 & 1 \\
\hline & Item14 & Appraiser1 & 1 & 1 & 1 & 2 & 5 & 5 & 1 & 4 & 5 & 2 & 1 & 1 & 1 & 4 & 1 & 3 & 3 & 1 & 1 & 1 \\
\hline & & Appraiser2 & 1 & 1 & 1 & 3 & 4 & 5 & 1 & 2 & 4 & 3 & 1 & 1 & 1 & 3 & 1 & 3 & 2 & 1 & 1 & 1 \\
\hline \multirow[t]{6}{*}{ Domain4 } & Item15 & Appraiser1 & 3 & 3 & 4 & 4 & 6 & 3 & 3 & 4 & 2 & 6 & 3 & 3 & 4 & 6 & 3 & 5 & 6 & 5 & 5 & 5 \\
\hline & & Appraiser2 & 2 & 2 & 5 & 5 & 5 & 2 & 2 & 5 & 2 & 5 & 2 & 3 & 4 & 6 & 3 & 5 & 4 & 5 & 6 & 5 \\
\hline & Item16 & Appraiser1 & 4 & 3 & 4 & 4 & 6 & 3 & 3 & 5 & 4 & 6 & 4 & 5 & 3 & 6 & 5 & 4 & 6 & 5 & 5 & 5 \\
\hline & & Appraiser2 & 5 & 4 & 5 & 5 & 5 & 4 & 4 & 5 & 5 & 5 & 5 & 5 & 5 & 4 & 5 & 4 & 4 & 5 & 6 & 5 \\
\hline & Item17 & Appraiser1 & 2 & 2 & 4 & 4 & 6 & 2 & 2 & 5 & 2 & 5 & 2 & 3 & 4 & 5 & 1 & 5 & 6 & 4 & 6 & 2 \\
\hline & & Appraiser2 & 2 & 2 & 5 & 5 & 6 & 3 & 2 & 6 & 3 & 6 & 2 & 3 & 3 & 6 & 1 & 5 & 5 & 5 & 6 & 3 \\
\hline \multirow[t]{4}{*}{ Domain5 } & Item18 & Appraiser1 & 3 & 3 & 3 & 3 & 3 & 3 & 3 & 4 & 3 & 3 & 3 & 3 & 4 & 4 & 3 & 4 & 4 & 4 & 4 & 2 \\
\hline & & Appraiser2 & 3 & 3 & 3 & 3 & 4 & 3 & 3 & 5 & 3 & 3 & 3 & 3 & 4 & 5 & 4 & 5 & 5 & 4 & 3 & 2 \\
\hline & Item19 & Appraiser1 & 1 & 1 & 5 & 5 & 5 & 4 & 4 & 5 & 5 & 5 & 1 & 4 & 5 & 5 & 4 & 5 & 5 & 5 & 5 & 1 \\
\hline & & Appraiser2 & 1 & 1 & 4 & 5 & 5 & 4 & 4 & 4 & 4 & 4 & 1 & 5 & 5 & 5 & 5 & 5 & 4 & 5 & 5 & 1 \\
\hline
\end{tabular}




\section{Appendix 2 Formulas}

1. The overall AGREE II scores of each guideline, each domain, and each item were calculated as follows:

AGREE II score of each guideline

$=\frac{\text { Total AGREE II scores of domains in each guildeline }}{\text { Toal number of domains }}$

AGREE II score of each domain

$=\frac{\text { Total AGREE II scores of guidelines in each domain }}{\text { Total number of guidelines }}$

2. The RIGHT reporting rates of each guideline, each domain, and each item were calculated as follows:

RIGHT reporting rate of each guideline

$=\frac{\text { Total number of "reported" in each guideline }}{\text { Total number of "reported" and "unreported" in each guideline }} * 100 \%$

RIGHT reporting rate of each domain

Total number of "reported" in each domain

$=\overline{\text { Total number of "reported" and "unreported" in each domain }}$

* $100 \%$

RIGHT reporting rate of each item

Total number of "reported" in each item

$=\overline{\text { Total number of "reported" and "unreported" in each item }}$

* $100 \%$ 
Table S2 RIGHT reporting quality for each item in each guideline

\begin{tabular}{|c|c|c|c|c|c|c|c|c|c|c|c|c|c|c|c|c|c|c|c|c|c|}
\hline Guideline & & 1 & 2 & 3 & 4 & 5 & 6 & 7 & 8 & 9 & 10 & 11 & 12 & 13 & 14 & 15 & 16 & 17 & 18 & 19 & 20 \\
\hline \multirow[t]{6}{*}{ Domain1 } & $1 a$ & $\mathrm{R}$ & $\mathrm{R}$ & $\mathrm{R}$ & $\mathrm{R}$ & $\mathrm{R}$ & $\mathrm{R}$ & $\mathrm{R}$ & $\mathrm{R}$ & $\mathrm{R}$ & $\mathrm{R}$ & $\mathrm{R}$ & $\mathrm{R}$ & $\mathrm{R}$ & $\mathrm{R}$ & $\mathrm{R}$ & $\mathrm{R}$ & $\mathrm{R}$ & $\mathrm{R}$ & $\mathrm{R}$ & $\mathrm{R}$ \\
\hline & $1 \mathrm{~b}$ & UR & UR & UR & UR & UR & UR & UR & UR & UR & UR & UR & UR & UR & UR & UR & UR & UR & UR & UR & UR \\
\hline & $1 \mathrm{c}$ & $\mathrm{R}$ & $\mathrm{R}$ & $\mathrm{R}$ & $\mathrm{R}$ & $\mathrm{R}$ & $\mathrm{R}$ & $\mathrm{R}$ & $\mathrm{R}$ & $\mathrm{R}$ & $\mathrm{R}$ & $\mathrm{R}$ & UR & $\mathrm{R}$ & $\mathrm{R}$ & UR & $\mathrm{R}$ & $\mathrm{R}$ & $\mathrm{R}$ & $\mathrm{R}$ & $\mathrm{R}$ \\
\hline & 2 & UR & $\mathrm{R}$ & $\mathrm{R}$ & $\mathrm{R}$ & $\mathrm{R}$ & UR & $\mathrm{R}$ & $\mathrm{R}$ & $\mathrm{R}$ & $\mathrm{R}$ & UR & $\mathrm{R}$ & $\mathrm{R}$ & UR & UR & $\mathrm{R}$ & $\mathrm{R}$ & R & $\mathrm{R}$ & $\mathrm{R}$ \\
\hline & 3 & UR & UR & UR & UR & UR & UR & UR & UR & UR & UR & UR & UR & UR & $\mathrm{R}$ & $\mathrm{R}$ & $\mathrm{R}$ & UR & UR & UR & UR \\
\hline & 4 & $\mathrm{R}$ & $\mathrm{R}$ & UR & UR & $\mathrm{R}$ & $\mathrm{R}$ & $\mathrm{R}$ & $\mathrm{R}$ & $\mathrm{R}$ & $\mathrm{R}$ & $\mathrm{R}$ & $\mathrm{R}$ & $\mathrm{R}$ & $\mathrm{R}$ & $\mathrm{R}$ & $\mathrm{R}$ & $\mathrm{R}$ & $\mathrm{R}$ & $\mathrm{R}$ & $\mathrm{R}$ \\
\hline \multirow[t]{8}{*}{ Domain2 } & 5 & $\mathrm{R}$ & UR & UR & $\mathrm{R}$ & $\mathrm{R}$ & UR & $\mathrm{R}$ & UR & UR & $\mathrm{R}$ & $\mathrm{R}$ & UR & $\mathrm{R}$ & $\mathrm{R}$ & UR & UR & UR & $\mathrm{R}$ & $\mathrm{R}$ & UR \\
\hline & 6 & $\mathrm{R}$ & $\mathrm{R}$ & $\mathrm{R}$ & $\mathrm{R}$ & $\mathrm{R}$ & $\mathrm{R}$ & $\mathrm{R}$ & $\mathrm{R}$ & $\mathrm{R}$ & $\mathrm{R}$ & $\mathrm{R}$ & $\mathrm{R}$ & $\mathrm{R}$ & $\mathrm{R}$ & UR & $\mathrm{R}$ & $\mathrm{R}$ & $\mathrm{R}$ & $\mathrm{R}$ & UR \\
\hline & $7 a$ & UR & UR & UR & $\mathrm{R}$ & $\mathrm{R}$ & $\mathrm{R}$ & $\mathrm{R}$ & $\mathrm{R}$ & $\mathrm{R}$ & $\mathrm{R}$ & $\mathrm{R}$ & $\mathrm{R}$ & $\mathrm{R}$ & $\mathrm{R}$ & $\mathrm{R}$ & $\mathrm{R}$ & $\mathrm{R}$ & $\mathrm{R}$ & $\mathrm{R}$ & $\mathrm{R}$ \\
\hline & $7 \mathrm{~b}$ & UR & UR & UR & $\mathrm{R}$ & $\mathrm{R}$ & $\mathrm{R}$ & $\mathrm{R}$ & $\mathrm{R}$ & $\mathrm{R}$ & $\mathrm{R}$ & $\mathrm{R}$ & $\mathrm{R}$ & $\mathrm{R}$ & $\mathrm{R}$ & $\mathrm{R}$ & $\mathrm{R}$ & $\mathrm{R}$ & $\mathrm{R}$ & $\mathrm{R}$ & $\mathrm{R}$ \\
\hline & $8 a$ & UR & UR & UR & UR & UR & $\mathrm{R}$ & UR & $\mathrm{R}$ & $\mathrm{R}$ & UR & $\mathrm{R}$ & $\mathrm{R}$ & UR & $\mathrm{R}$ & UR & $\mathrm{R}$ & $\mathrm{R}$ & UR & $\mathrm{R}$ & UR \\
\hline & $8 b$ & $\mathrm{R}$ & UR & $\mathrm{R}$ & $\mathrm{R}$ & $\mathrm{R}$ & UR & UR & $\mathrm{R}$ & $\mathrm{R}$ & UR & $\mathrm{R}$ & UR & UR & $\mathrm{R}$ & UR & UR & $\mathrm{R}$ & $\mathrm{R}$ & UR & UR \\
\hline & $9 a$ & UR & UR & UR & $\mathrm{R}$ & $\mathrm{R}$ & UR & UR & UR & UR & UR & $\mathrm{R}$ & UR & UR & $\mathrm{R}$ & UR & $\mathrm{R}$ & $\mathrm{R}$ & UR & UR & UR \\
\hline & $9 b$ & $\mathrm{R}$ & $\mathrm{R}$ & UR & $\mathrm{R}$ & $\mathrm{R}$ & $\mathrm{R}$ & $\mathrm{R}$ & $\mathrm{R}$ & $\mathrm{R}$ & $\mathrm{R}$ & $\mathrm{R}$ & UR & $\mathrm{R}$ & $\mathrm{R}$ & $\mathrm{R}$ & $\mathrm{R}$ & $\mathrm{R}$ & R & $\mathrm{R}$ & $\mathrm{R}$ \\
\hline \multirow[t]{5}{*}{ Domain3 } & $10 a$ & $\mathrm{R}$ & $\mathrm{R}$ & $\mathrm{R}$ & $\mathrm{R}$ & $\mathrm{R}$ & UR & $\mathrm{R}$ & $\mathrm{R}$ & $\mathrm{R}$ & $\mathrm{R}$ & $\mathrm{R}$ & $\mathrm{R}$ & $\mathrm{R}$ & $\mathrm{R}$ & $\mathrm{R}$ & $\mathrm{B}$ & $\mathrm{R}$ & $\mathrm{R}$ & $\mathrm{R}$ & $\mathrm{R}$ \\
\hline & $10 b$ & UR & UR & UR & UR & $\mathrm{R}$ & UR & UR & UR & $\mathrm{R}$ & $\mathrm{R}$ & UR & UR & UR & $\mathrm{R}$ & UR & $\mathrm{R}$ & UR & UR & UR & UR \\
\hline & $11 a$ & UR & UR & UR & UR & UR & UR & UR & UR & UR & UR & UR & UR & UR & $\mathrm{R}$ & UR & UR & UR & UR & UR & UR \\
\hline & $11 b$ & UR & UR & UR & UR & UR & UR & UR & UR & UR & UR & UR & UR & UR & UR & UR & UR & UR & UR & UR & UR \\
\hline & 12 & UR & UR & UR & UR & $\mathrm{R}$ & UR & UR & UR & UR & $\mathrm{R}$ & UR & UR & UR & $\mathrm{R}$ & UR & UR & UR & UR & UR & UR \\
\hline \multirow[t]{7}{*}{ Domain4 } & $13 a$ & $\mathrm{R}$ & $\mathrm{R}$ & $\mathrm{R}$ & $\mathrm{R}$ & $\mathrm{R}$ & $\mathrm{R}$ & $\mathrm{R}$ & $\mathrm{R}$ & $\mathrm{R}$ & $\mathrm{R}$ & r & $\mathrm{R}$ & $\mathrm{R}$ & $\mathrm{R}$ & $\mathrm{R}$ & $\mathrm{D}$ & $n$ & $\mathrm{R}$ & $\mathrm{R}$ & $\mathrm{R}$ \\
\hline & $13 b$ & $\mathrm{R}$ & $\mathrm{R}$ & $\mathrm{R}$ & $\mathrm{R}$ & $\mathrm{R}$ & $\mathrm{R}$ & $\mathrm{R}$ & $\mathrm{R}$ & $\mathrm{R}$ & $\mathrm{R}$ & $\mathrm{R}$ & $\mathrm{R}$ & $\mathrm{R}$ & $\mathrm{R}$ & $\mathrm{R}$ & $R$ & $\mathrm{R}$ & $R$ & $\mathrm{R}$ & $\mathrm{R}$ \\
\hline & $13 c$ & UR & UR & UR & UR & $\mathrm{R}$ & UR & UR & UR & UR & UR & UR & UR & UR & $\mathrm{R}$ & UR & UR & $\mathrm{R}$ & UR & UR & UR \\
\hline & $14 a$ & UR & UR & UR & UR & $\mathrm{R}$ & UR & UR & $\mathrm{R}$ & UR & UR & UR & $\mathrm{R}$ & $\mathrm{R}$ & $\mathrm{R}$ & $\mathrm{R}$ & $\mathrm{R}$ & UR & R & UR & $\mathrm{R}$ \\
\hline & $14 b$ & $\mathrm{R}$ & $\mathrm{R}$ & UR & $\mathrm{R}$ & $\mathrm{R}$ & $\mathrm{R}$ & UR & $\mathrm{R}$ & $\mathrm{R}$ & $\mathrm{R}$ & UR & $\mathrm{R}$ & $\mathrm{R}$ & $\mathrm{R}$ & $\mathrm{R}$ & $\mathrm{R}$ & $\mathrm{R}$ & $\mathrm{R}$ & $\mathrm{R}$ & $\mathrm{R}$ \\
\hline & $14 c$ & $\mathrm{R}$ & UR & $\mathrm{R}$ & UR & $\mathrm{R}$ & UR & UR & $\mathrm{R}$ & UR & UR & $\mathrm{R}$ & UR & UR & $\mathrm{R}$ & UR & $\mathrm{R}$ & UR & $\mathrm{R}$ & UR & UR \\
\hline & 15 & UR & UR & UR & UR & $\mathrm{R}$ & UR & UR & $\mathrm{R}$ & UR & $\mathrm{R}$ & UR & UR & UR & $\mathrm{R}$ & UR & $\mathrm{n}$ & $\mathrm{R}$ & $\mathrm{R}$ & $n$ & UR \\
\hline \multirow[t]{2}{*}{ Domain5 } & 16 & UR & UR & UR & $\mathrm{R}$ & UR & UR & UR & UR & $\mathrm{R}$ & UR & UR & UR & UR & $\mathrm{R}$ & UR & UR & $\mathrm{R}$ & $\mathrm{R}$ & UR & UR \\
\hline & 17 & UR & UR & UR & $\mathrm{R}$ & UR & UR & UR & UR & UR & UR & $\mathrm{R}$ & UR & UR & $\mathrm{R}$ & UR & UR & $\mathrm{R}$ & $\mathrm{R}$ & UR & UR \\
\hline \multirow[t]{4}{*}{ Domain6 } & $18 a$ & $\mathrm{R}$ & UR & UR & UR & UR & $\mathrm{R}$ & UR & UR & UR & $\mathrm{R}$ & $\mathrm{R}$ & UR & UR & $\mathrm{R}$ & $\mathrm{R}$ & $\mathrm{R}$ & UR & UR & UR & UR \\
\hline & $18 b$ & UR & UR & UR & UR & UR & UR & UR & UR & UR & UR & UR & UR & UR & UR & UR & UR & UR & UR & UR & UR \\
\hline & $19 a$ & $\mathrm{R}$ & $\mathrm{R}$ & UR & UR & UR & $\mathrm{R}$ & $\mathrm{R}$ & UR & UR & $\mathrm{R}$ & $\mathrm{R}$ & UR & $\mathrm{R}$ & $\mathrm{R}$ & $\mathrm{R}$ & $\mathrm{R}$ & $\mathrm{R}$ & $\mathrm{R}$ & $\mathrm{R}$ & $\mathrm{R}$ \\
\hline & $19 b$ & UR & UR & UR & UR & UR & UR & UR & UR & UR & UR & UR & UR & UR & $\mathrm{R}$ & UR & $\mathrm{R}$ & UR & UR & UR & UR \\
\hline \multirow[t]{3}{*}{ Domain7 } & 20 & UR & $\mathrm{R}$ & $\mathrm{R}$ & UR & $\mathrm{R}$ & $\mathrm{R}$ & $\mathrm{R}$ & $\mathrm{R}$ & $\mathrm{R}$ & UR & UR & UR & $\mathrm{R}$ & $\mathrm{R}$ & $\mathrm{R}$ & $\mathrm{R}$ & $\mathrm{R}$ & $\mathrm{R}$ & $\mathrm{R}$ & UR \\
\hline & 21 & UR & UR & $\mathrm{R}$ & $\mathrm{R}$ & $\mathrm{R}$ & UR & $\mathrm{R}$ & $\mathrm{R}$ & $\mathrm{R}$ & $\mathrm{R}$ & $\mathrm{R}$ & UR & $\mathrm{R}$ & $\mathrm{R}$ & $\mathrm{R}$ & $\mathrm{R}$ & $\mathrm{R}$ & $\mathrm{R}$ & $\mathrm{R}$ & UR \\
\hline & 22 & UR & UR & UR & $\mathrm{R}$ & $\mathrm{R}$ & UR & UR & $\mathrm{R}$ & UR & $\mathrm{R}$ & UR & UR & $\mathrm{R}$ & $\mathrm{R}$ & UR & $\mathrm{R}$ & $\mathrm{R}$ & $\mathrm{R}$ & UR & UR \\
\hline
\end{tabular}

$R$, reported; UR, unreported 


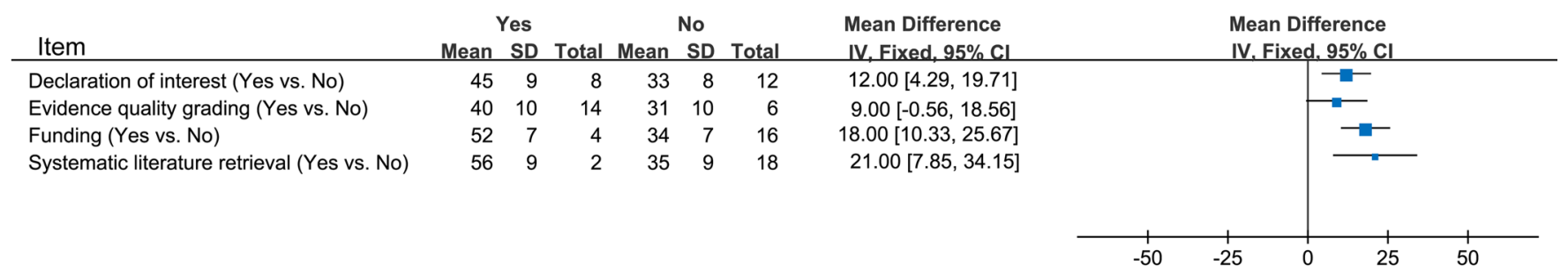

Figure S1 Weight mean difference (WMD) of AGREE II score between groups.

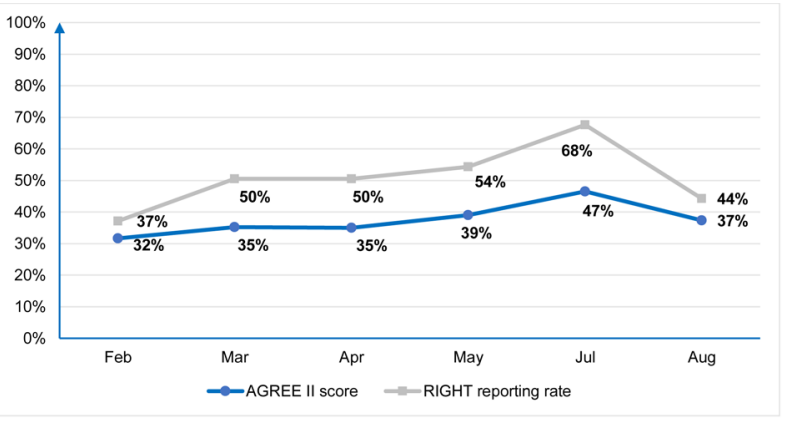

Figure S2 AGREE II score and reporting rate in the RIGHT checklist reported by month.

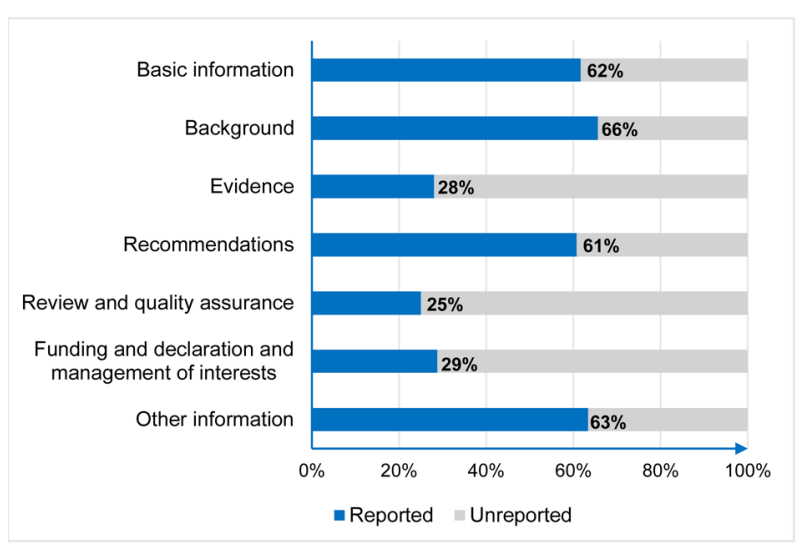

Figure S3 Percentage of reporting items in each domain in the RIGHT checklist.

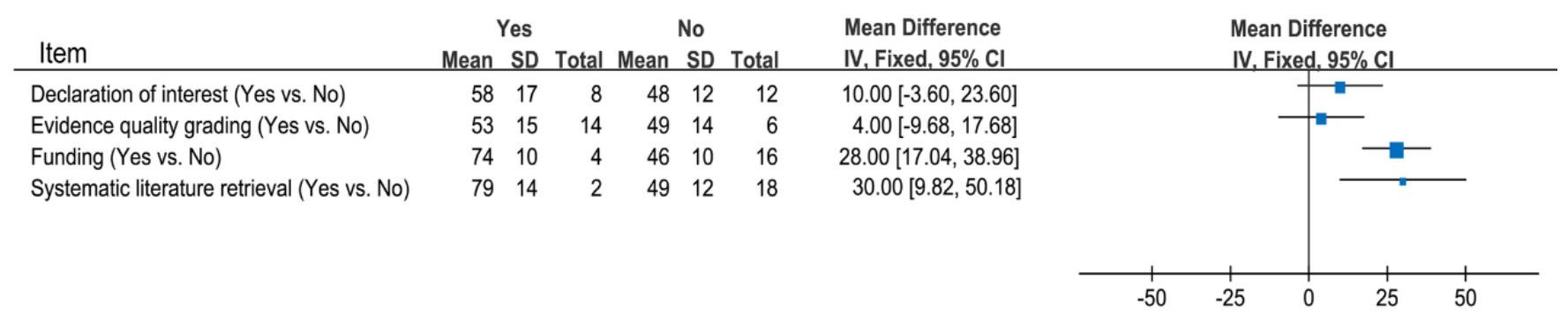

Figure S4 Difference of reporting rates in the RIGHT checklist between groups. 
Table S3 Summary of recommendations for antivirus drugs by included guidelines

\begin{tabular}{|c|c|c|c|c|c|c|c|c|}
\hline Guideline & Ribavirin & Interferon & Remdesivir & Lopinavir/ritonavir & Chloroquine/Hydroxy-chloroquine & Abidol & Oseltamivir & Favipiravir \\
\hline 1 & Not recommend & $\begin{array}{l}\text { Recommend } \\
\text { Dosing regimen: } \\
\text { Interferon- } a \text { 2 b nebulization: } \\
\text { 100,000-200,000 IU/kg for mild } \\
\text { cases, and 200,000-400,000 IU/ } \\
\text { kg for severe cases, two times/ } \\
\text { day for 5-7 days }\end{array}$ & Not recommend & Not recommend & Not recommend & $\begin{array}{l}\text { Not } \\
\text { recommend }\end{array}$ & Not recommend & $\begin{array}{l}\text { Not } \\
\text { recommend }\end{array}$ \\
\hline 2 & Not recommend & Not recommend & Not recommend & Not recommend & Not recommend & $\begin{array}{l}\text { Not } \\
\text { recommend }\end{array}$ & Not recommend & $\begin{array}{l}\text { Not } \\
\text { recommend }\end{array}$ \\
\hline 3 & Not recommend & Not recommend & $\begin{array}{l}\text { Recommend } \\
\text { Dosing regimen: } \\
<40 \mathrm{~kg}: 5 \mathrm{mg} / \mathrm{kg} \text { IV loading dose on } \\
\text { day } 1 \text {; followed by } 2.5 \mathrm{mg} / \mathrm{kg} \text { IV q } 24 \mathrm{~h} \\
>40 \mathrm{~kg}: 200 \mathrm{mg} \text { IV loading dose on day } \\
1 \text {; followed by } 100 \mathrm{mg} \text { IV q24h }\end{array}$ & Not recommend & Not recommend & $\begin{array}{l}\text { Not } \\
\text { recommend }\end{array}$ & Not recommend & $\begin{array}{l}\text { Not } \\
\text { recommend }\end{array}$ \\
\hline 4 & Not recommend & Not recommend & Not recommend & Not recommend & Not recommend & $\begin{array}{l}\text { Not } \\
\text { recommend }\end{array}$ & Not recommend & $\begin{array}{l}\text { Not } \\
\text { recommend }\end{array}$ \\
\hline 5 & Not recommend & Not recommend & Not recommend & Not recommend & Not recommend & $\begin{array}{l}\text { Not } \\
\text { recommend }\end{array}$ & Not recommend & $\begin{array}{l}\text { Not } \\
\text { recommend }\end{array}$ \\
\hline 7 & Not recommend & Not recommend & Recommend for severe case & $\begin{array}{l}\text { Recommend } \\
\text { Dosing regimen: } \\
\text { Age >6 months and < } 18 \text { years } \\
7-15 \mathrm{~kg}: 12 / 3 \mathrm{mg} / \mathrm{kg}, 15-40 \mathrm{~kg}: 10 / 2.5 \mathrm{mg} / \\
\mathrm{kg},>40 \mathrm{~kg}: 400 \mathrm{mg} / 100 \mathrm{mg} \text {; every } 12 \mathrm{~h} \\
\text { Age } 2 \text { weeks to } 6 \text { months } \\
16 / 4 \mathrm{mg} / \mathrm{kg} \text { (equivalent to } 0.2 \mathrm{~mL} / \mathrm{kg} \text { ), given } \\
\text { twice daily with food }\end{array}$ & Not recommend & $\begin{array}{l}\text { Not } \\
\text { recommend }\end{array}$ & Not recommend & $\begin{array}{l}\text { Not } \\
\text { recommend }\end{array}$ \\
\hline 8 & Not recommend & Not recommend & Not recommend & Not recommend & Not recommend & $\begin{array}{l}\text { Not } \\
\text { recommend }\end{array}$ & Not recommend & $\begin{array}{l}\text { Not } \\
\text { recommend }\end{array}$ \\
\hline 9 & Not recommend & Not recommend & Not recommend & Not recommend & Not recommend & $\begin{array}{l}\text { Not } \\
\text { recommend }\end{array}$ & Not recommend & $\begin{array}{l}\text { Not } \\
\text { recommend }\end{array}$ \\
\hline 10 & Not recommend & Not report & $\begin{array}{l}\text { Recommend for critical case } \\
\text { Dosing regimen: } \\
\text { < } 40 \mathrm{~kg}: 5 \mathrm{mg} / \mathrm{kg} \text { IV loading dose on } \\
\text { day 1; followed by } 2.5 \mathrm{mg} / \mathrm{kg} \text { IV q2 } 4 \mathrm{~h} \\
>40 \mathrm{~kg}: 200 \mathrm{mg} \text { IV loading dose on day } \\
\text { 1; followed by } 100 \mathrm{mg} \text { IV q24h } \\
\text { Recommended duration: Up to } 10 \\
\text { days, with 5-day duration favored for } \\
\text { fast responders }\end{array}$ & Not recommend & $\begin{array}{l}\text { Recommend } \\
\text { Dosing regimen: } \\
13 \mathrm{mg} / \mathrm{kg} \text { (maximum: } 800 \mathrm{mg} \text { ) PO } \\
\text { followed by } 6.5 \mathrm{mg} / \mathrm{kg} \text { (maximum: } \\
400 \mathrm{mg} \text { ) PO at } 6,24 \text {, and } 48 \text { hours } \\
\text { after initial dose (duration could be } \\
\text { extended for up to } 5 \text { days on a case- } \\
\text { by-case basis) } \\
\mathrm{OR} 6.5 \mathrm{mg} / \mathrm{kg} / \mathrm{dose} \text { (maximum: } 400 \\
\mathrm{mg} / \mathrm{dose} \text { ) PO bid on day } 1 \text {, followed } \\
\text { by } 3.25 \mathrm{mg} / \mathrm{kg} / \text { dose (maximum: } 200 \\
\mathrm{mg} / \text { dose) PO bid for up to } 5 \text { days } \\
\text { Neonates: dosing not established; } \\
\text { consider use on a case-by-case basis } \\
\text { Recommended duration: No more } \\
\text { than } 5 \text { days. The duration studied for } \\
\text { acute malaria is } 3 \text { days. }\end{array}$ & Not report & Not report & Not report \\
\hline 11 & Not recommend & $\begin{array}{l}\text { Recommend } \\
\text { Dosing regimen: } \\
\text { IFN- } a \text { spray: } 1-2 \text { sprays on } \\
\text { each side of the nasal cavity, } \\
8-10 \text { sprays to the oropharynx } \\
\text { for } 8-10 \text { times/day, with a } \\
\text { treatment course of } 5-7 \text { days for } \\
\text { high-risk children who had close } \\
\text { contact with suspected patients } \\
\text { or those with upper respiratory } \\
\text { tract symptoms in the early } \\
\text { stage of virus infection. } \\
\text { IFN- } \text { n nebulization: } 200,000- \\
400,000 \text { IU } / \mathrm{kg} \text { or } 2-4 \mu g / \mathrm{kg}, 2 \\
\text { times/day, at a treatment course } \\
\text { of 5-7 days. }\end{array}$ & Not recommend & Not recommend & Not recommend & $\begin{array}{l}\text { Not } \\
\text { recommend }\end{array}$ & Not recommend & $\begin{array}{l}\text { Not } \\
\text { recommend }\end{array}$ \\
\hline 12 & Not recommend & Not recommend & Not recommend & Not recommend & Not recommend & $\begin{array}{l}\text { Not } \\
\text { recommend }\end{array}$ & Not recommend & $\begin{array}{l}\text { Not } \\
\text { recommend }\end{array}$ \\
\hline 14 & Not recommend & Not recommend & Not recommend & Not recommend & Not recommend & $\begin{array}{l}\text { Not } \\
\text { recommend }\end{array}$ & Not recommend & $\begin{array}{l}\text { Not } \\
\text { recommend }\end{array}$ \\
\hline 15 & Not report & Not report & $\begin{array}{l}\text { Recommend } \\
\text { Dosing regimen: } \\
5 \mathrm{mg} / \mathrm{kg} \text { load IV once (max dose } 200 \\
\mathrm{mg} \text { ) on day } 1 \text {, then } 2.5 \mathrm{mg} / \mathrm{kg}(100 \mathrm{mg} \\
\mathrm{max} \text { dose) IV daily for } 9 \text { days. }\end{array}$ & Not report & Not report & Not report & Not report & Not report \\
\hline 19 & Not report & Not recommend & Not report & Not report & Not report & Not report & Not report & Not report \\
\hline 20 & $\begin{array}{l}\text { Recommend } \\
\text { Dosing regimen: } \\
10 \mathrm{mg} / \mathrm{kg} / \mathrm{time} \text {, } \\
\text { via intravenous } \\
\text { infusion, } 2 \text { to } 3 \\
\text { times daily }\end{array}$ & $\begin{array}{l}\text { Recommend } \\
\text { Dosing regimen: } \\
200,000 \text { to } 400,000 \mathrm{IU} / \mathrm{kg} \\
\text { in } 2 \mathrm{~mL} \text { sterile water, with } \\
\text { nebulization two times per day } \\
\text { for } 5-7 \text { days }\end{array}$ & Recommend & $\begin{array}{l}\text { Recommend } \\
\text { Dosing regimen: } \\
\text { Weight } 7-15 \mathrm{~kg}, 12 \mathrm{mg} / 3 \mathrm{mg} / \mathrm{kg} \text {; weight } \\
15-40 \mathrm{~kg}, 400 \mathrm{mg} / 100 \mathrm{mg} \text { as adult each } \\
\text { time, twice a day for } 1-2 \text { weeks }\end{array}$ & $\begin{array}{l}\text { Recommend } \\
\text { Dosing regimen: } \\
3-5 \mathrm{mg} / \mathrm{kg} / \text { day (max dose } 400 \mathrm{mg} \text { ), } \\
\text { twice daily for } 5 \text { days }\end{array}$ & $\begin{array}{l}\text { Not } \\
\text { recommend }\end{array}$ & Not recommend & Recommend \\
\hline
\end{tabular}


Table S4 Summary of supporting evidences for recommendations for remdesivir

\begin{tabular}{|c|c|c|c|c|c|c|c|c|c|c|}
\hline \multirow[b]{2}{*}{ Guideline } & \multirow[b]{2}{*}{ Recommendation } & \multirow{2}{*}{$\begin{array}{c}\text { Reference } \\
\text { number }\end{array}$} & \multicolumn{8}{|c|}{ Study type of supporting evidence } \\
\hline & & & $\begin{array}{l}\text { Guidelines/ } \\
\text { Consensuses }\end{array}$ & SR/meta-analysis & Review & $\mathrm{RCT} / \mathrm{CCT}$ & $\begin{array}{l}\text { Cohort } \\
\text { studies }\end{array}$ & $\begin{array}{c}\text { Case-control } \\
\text { studies }\end{array}$ & $\begin{array}{l}\text { Case series/ } \\
\text { case reports }\end{array}$ & $\begin{array}{c}\text { Animal studies/ } \\
\text { in vivo studies }\end{array}$ \\
\hline 1 & Not recommend & 0 & 0 & 0 & 0 & 0 & 0 & 0 & 0 & 0 \\
\hline 2 & Not recommend & 0 & 0 & 0 & 0 & 0 & 0 & 0 & 0 & 0 \\
\hline 3 & Recommend & 2 & 0 & 0 & 0 & 2 & 0 & 0 & 0 & 0 \\
\hline 4 & Not recommend & 2 & 0 & 0 & 0 & 1 & 0 & 0 & 0 & 1 \\
\hline 5 & Not recommend & 1 & 1 & 0 & 0 & 0 & 0 & 0 & 0 & 0 \\
\hline 7 & Recommend & 2 & 0 & 0 & 0 & 0 & 0 & 0 & 1 & 1 \\
\hline 8 & Not recommend & 1 & 0 & 0 & 0 & 0 & 0 & 0 & 0 & 1 \\
\hline 9 & Not recommend & 0 & 0 & 0 & 0 & 0 & 0 & 0 & 0 & 0 \\
\hline 10 & Recommend & 13 & 0 & 0 & 0 & 1 & 0 & 0 & 1 & 11 \\
\hline 11 & Not recommend & 0 & 0 & 0 & 0 & 0 & 0 & 0 & 0 & 0 \\
\hline 12 & Not recommend & 0 & 0 & 0 & 0 & 0 & 0 & 0 & 0 & 0 \\
\hline 14 & Not recommend & 0 & 0 & 0 & 0 & 0 & 0 & 0 & 0 & 0 \\
\hline 15 & Recommend & 0 & 0 & 0 & 0 & 0 & 0 & 0 & 0 & 0 \\
\hline 20 & Recommend & 3 & 0 & 0 & 2 & 0 & 0 & 0 & 0 & 1 \\
\hline
\end{tabular}

\begin{tabular}{|c|c|c|c|c|c|c|c|c|c|}
\hline \multirow{3}{*}{ Guideline } & \multirow{3}{*}{ Recommendation } & \multicolumn{8}{|c|}{ Supporting evidence } \\
\hline & & \multicolumn{4}{|c|}{ Evidence source of SR/Meta-analysis } & \multicolumn{4}{|c|}{ Evidence source of original studies } \\
\hline & & $\begin{array}{l}\text { Children with } \\
\text { COVID-19 }\end{array}$ & $\begin{array}{l}\text { Patient with } \\
\text { COVID-19 }\end{array}$ & Other evidence & $\begin{array}{l}\text { The proportion of } \\
\text { direct evidence }\end{array}$ & $\begin{array}{l}\text { Children with } \\
\text { COVID-19 }\end{array}$ & $\begin{array}{l}\text { Patient with } \\
\text { COVID-19 }\end{array}$ & $\begin{array}{c}\text { Other } \\
\text { evidence }\end{array}$ & $\begin{array}{l}\text { The proportion of } \\
\text { direct evidence }\end{array}$ \\
\hline 1 & Not recommend & 0 & 0 & 0 & NA & 0 & 0 & 0 & NA \\
\hline 2 & Not recommend & 0 & 0 & 0 & NA & 0 & 0 & 0 & NA \\
\hline 3 & Recommend & 0 & 0 & 0 & NA & 0 & 0 & 2 & $0 \%$ \\
\hline 4 & Not recommend & 0 & 0 & 0 & NA & 0 & 1 & 1 & $0 \%$ \\
\hline 5 & Not recommend & 0 & 0 & 0 & NA & 0 & 0 & 0 & NA \\
\hline 7 & Recommend & 0 & 0 & 0 & NA & 0 & 1 & 1 & $0 \%$ \\
\hline 8 & Not recommend & 0 & 0 & 0 & NA & 0 & 0 & 1 & $0 \%$ \\
\hline 9 & Not recommend & 0 & 0 & 0 & NA & 0 & 0 & 0 & NA \\
\hline 10 & Recommend & 0 & 0 & 0 & NA & 0 & 1 & 12 & $0 \%$ \\
\hline 11 & Not recommend & 0 & 0 & 0 & NA & 0 & 0 & 0 & NA \\
\hline 12 & Not recommend & 0 & 0 & 0 & NA & 0 & 0 & 0 & NA \\
\hline 14 & Not recommend & 0 & 0 & 0 & NA & 0 & 0 & 0 & NA \\
\hline 15 & Recommend & 0 & 0 & 0 & NA & 0 & 0 & 0 & NA \\
\hline 20 & Recommend & 0 & 0 & 0 & NA & 0 & 0 & 1 & $0 \%$ \\
\hline
\end{tabular}

Original studies include RCT/CCT, cohort studies, case-control studies, case series/case reports, animal studies and in vivo studies. Other evidence includes studies of patients with other diseases, animal studies or in vivo studies. The proportion of direct evidence, evidence from children with COVID-19/(evidence from patients with COVID-19 + other evidence). NA, not applicable; CCT, clinical controlled trials; RCT, randomized controlled trials; SR, systematic review. 
Table S5 Summary of supporting evidences for recommendations for interferon

\begin{tabular}{|c|c|c|c|c|c|c|c|c|c|c|}
\hline \multirow[b]{2}{*}{ Guideline } & \multirow[b]{2}{*}{ Recommendation } & \multirow{2}{*}{$\begin{array}{c}\text { Reference } \\
\text { number }\end{array}$} & \multicolumn{8}{|c|}{ Study type of supporting evidence } \\
\hline & & & $\begin{array}{l}\text { Guidelines/ } \\
\text { consensuses }\end{array}$ & $\begin{array}{l}\text { SR/meta- } \\
\text { analysis }\end{array}$ & Review & RCT/CCT & $\begin{array}{l}\text { Cohort } \\
\text { studies }\end{array}$ & $\begin{array}{l}\text { Case-control } \\
\text { studies }\end{array}$ & $\begin{array}{c}\text { Case series/case } \\
\text { reports }\end{array}$ & $\begin{array}{c}\text { Animal studies/ } \\
\text { in vivo studies }\end{array}$ \\
\hline 1 & Recommend & 0 & 0 & 0 & 0 & 0 & 0 & 0 & 0 & 0 \\
\hline 2 & Not recommend & 0 & 0 & 0 & 0 & 0 & 0 & 0 & 0 & 0 \\
\hline 3 & Not recommend & 0 & 0 & 0 & 0 & 0 & 0 & 0 & 0 & 0 \\
\hline 4 & Not recommend & 0 & 0 & 0 & 0 & 0 & 0 & 0 & 0 & 0 \\
\hline 5 & Not recommend & 1 & 1 & 0 & 0 & 0 & 0 & 0 & 0 & 0 \\
\hline 7 & Not recommend & 1 & 0 & 0 & 1 & 0 & 0 & 0 & 0 & 0 \\
\hline 8 & Not recommend & 1 & 0 & 0 & 1 & 0 & 0 & 0 & 0 & 0 \\
\hline 9 & Not recommend & 0 & 0 & 0 & 0 & 0 & 0 & 0 & 0 & 0 \\
\hline 11 & Recommend & 11 & 5 & 0 & 1 & 1 & 1 & 0 & 0 & 3 \\
\hline 12 & Not recommend & 0 & 0 & 0 & 0 & 0 & 0 & 0 & 0 & 0 \\
\hline 14 & Not recommend & 1 & 0 & 1 & 0 & 0 & 0 & 0 & 0 & 0 \\
\hline 19 & Not recommend & 21 & 0 & 0 & 6 & 3 & 3 & 1 & 4 & 4 \\
\hline 20 & Recommend & 1 & 1 & 0 & 0 & 0 & 0 & 0 & 0 & 0 \\
\hline
\end{tabular}

\begin{tabular}{|c|c|c|c|c|c|c|c|c|c|}
\hline \multirow{3}{*}{ Guideline } & \multirow{3}{*}{ Recommendation } & \multicolumn{8}{|c|}{ Supporting evidence } \\
\hline & & \multicolumn{4}{|c|}{ Evidence source of $\mathrm{SR} /$ meta-analysis } & \multicolumn{4}{|c|}{ Evidence source of original studies } \\
\hline & & $\begin{array}{l}\text { Children with } \\
\text { COVID-19 }\end{array}$ & $\begin{array}{l}\text { Patient with } \\
\text { COVID-19 }\end{array}$ & $\begin{array}{c}\text { Other } \\
\text { evidence }\end{array}$ & $\begin{array}{l}\text { The proportion of } \\
\text { direct evidence }\end{array}$ & $\begin{array}{l}\text { Children with } \\
\text { COVID-19 }\end{array}$ & $\begin{array}{l}\text { Patient with } \\
\text { COVID-19 }\end{array}$ & $\begin{array}{l}\text { Other } \\
\text { evidence }\end{array}$ & $\begin{array}{l}\text { The proportion of } \\
\text { direct evidence }\end{array}$ \\
\hline 1 & Recommend & 0 & 0 & 0 & NA & 0 & 0 & 0 & NA \\
\hline 2 & Not recommend & 0 & 0 & 0 & NA & 0 & 0 & 0 & NA \\
\hline 3 & Not recommend & 0 & 0 & 0 & NA & 0 & 0 & 0 & NA \\
\hline 4 & Not recommend & 0 & 0 & 0 & NA & 0 & 0 & 0 & NA \\
\hline 5 & Not recommend & 0 & 0 & 0 & NA & 0 & 0 & 0 & NA \\
\hline 7 & Not recommend & 0 & 0 & 0 & NA & 0 & 0 & 0 & NA \\
\hline 8 & Not recommend & 0 & 0 & 0 & NA & 0 & 0 & 0 & NA \\
\hline 9 & Not recommend & 0 & 0 & 0 & NA & 0 & 0 & 0 & NA \\
\hline 11 & Recommend & 0 & 0 & 0 & NA & 0 & 0 & 5 & $0 \%$ \\
\hline 12 & Not recommend & 0 & 0 & 0 & NA & 0 & 0 & 0 & NA \\
\hline 14 & Not recommend & 0 & 0 & 5 & $0 \%$ & 0 & 0 & 0 & NA \\
\hline 19 & Not recommend & 0 & 0 & 0 & NA & 0 & 8 & 7 & $0 \%$ \\
\hline 20 & Recommend & 0 & 0 & 0 & NA & 0 & 0 & 0 & NA \\
\hline
\end{tabular}

Original studies include RCT/CCT, cohort studies, case-control studies, case series/case reports, animal studies and in vivo studies. Other evidence includes studies of patients with other diseases, animal studies or in vivo studies. The proportion of direct evidence, evidence from children with COVID-19/(evidence from patients with COVID-19 + other evidence). NA, not applicable; CCT, clinical controlled trials; RCT, randomized controlled trials; SR, systematic review. 
Table S6 Summary of recommendations for glucocorticoids by included guidelines

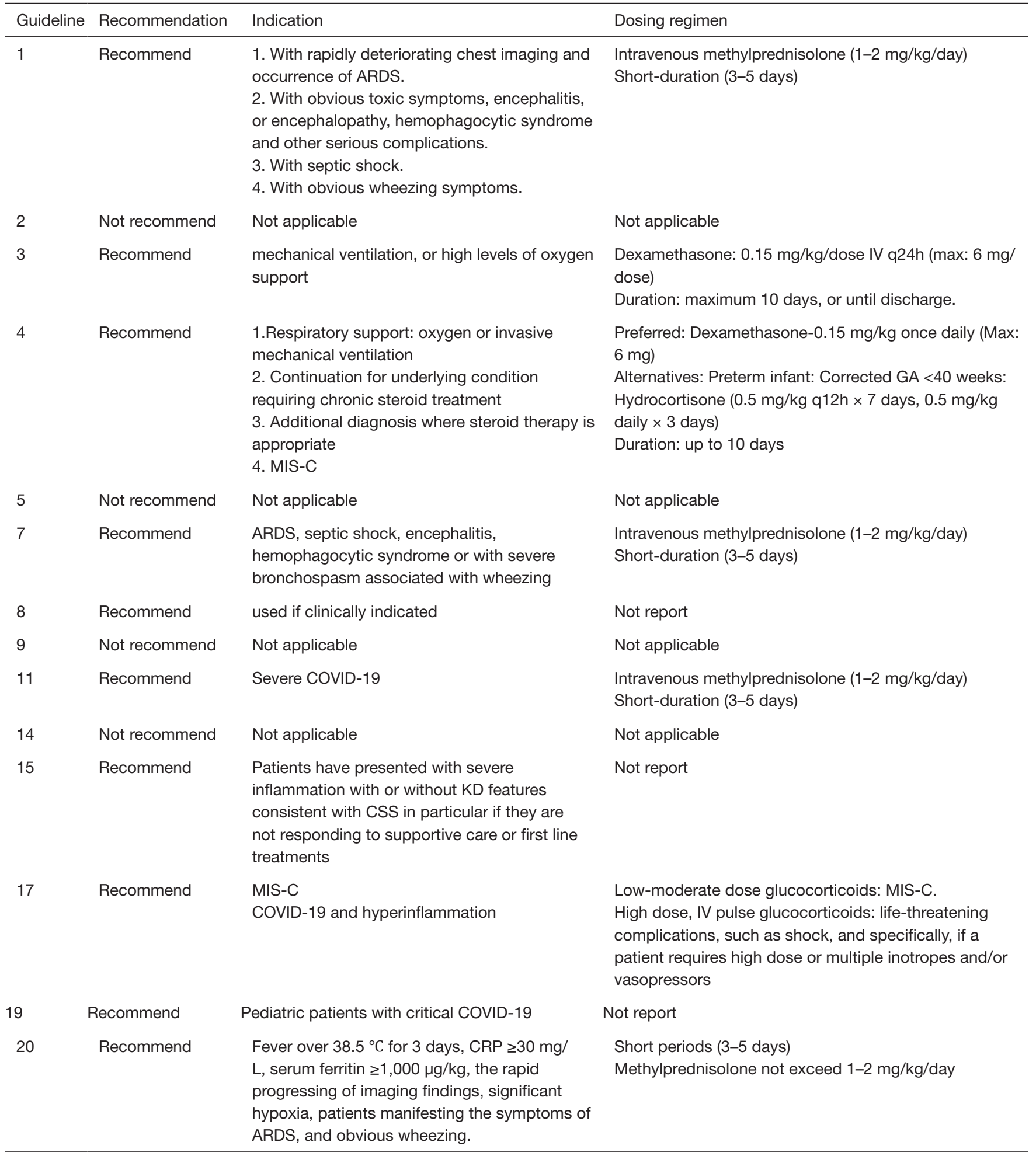

ARDS, acute respiratory distress syndrome; MIS-C, multisystem inflammatory syndrome in children; GA, gestational age; KD, Kawasaki disease; CSS, cytokine storm syndrome 
Table S7 Summary of supporting evidences for recommendations for glucocorticoid

\begin{tabular}{|c|c|c|c|c|c|c|c|c|c|c|}
\hline \multirow[b]{2}{*}{ Guideline } & \multirow[b]{2}{*}{ Recommendation } & \multirow{2}{*}{$\begin{array}{l}\text { Reference } \\
\text { number }\end{array}$} & \multicolumn{8}{|c|}{ Study type of supporting evidence } \\
\hline & & & $\begin{array}{l}\text { Guidelines/ } \\
\text { consensuses }\end{array}$ & $\begin{array}{l}\mathrm{SR} / \text { meta- } \\
\text { analysis }\end{array}$ & Review & $\mathrm{RCT} / \mathrm{CCT}$ & Cohort studies & $\begin{array}{l}\text { Case-control } \\
\text { studies }\end{array}$ & $\begin{array}{l}\text { Case series/ } \\
\text { case reports }\end{array}$ & $\begin{array}{l}\text { Animal studies/ } \\
\text { in vivo studies }\end{array}$ \\
\hline 1 & Recommend & 5 & 3 & 0 & 1 & 0 & 1 & 0 & 0 & 0 \\
\hline 2 & Not recommend & 0 & 0 & 0 & 0 & 0 & 0 & 0 & 0 & 0 \\
\hline 3 & Recommend & 1 & 0 & 0 & 0 & 1 & 0 & 0 & 0 & 0 \\
\hline 4 & Recommend & 2 & 0 & 0 & 0 & 2 & 0 & 0 & 0 & 0 \\
\hline 5 & Not recommend & 1 & 1 & 0 & 0 & 0 & 0 & 0 & 0 & 0 \\
\hline 7 & Recommend & 5 & 3 & 0 & 0 & 0 & 2 & 0 & 0 & 0 \\
\hline 8 & Recommend & 0 & 0 & 0 & 0 & 0 & 0 & 0 & 0 & 0 \\
\hline 9 & Not recommend & 0 & 0 & 0 & 0 & 0 & 0 & 0 & 0 & 0 \\
\hline 11 & Recommend & 0 & 0 & 0 & 0 & 0 & 0 & 0 & 0 & 0 \\
\hline 14 & Not recommend & 1 & 0 & 1 & 0 & 0 & 0 & 0 & 0 & 0 \\
\hline 15 & Recommend & 0 & 0 & 0 & 0 & 0 & 0 & 0 & 0 & 0 \\
\hline 17 & Recommend & 19 & 0 & 4 & 0 & 10 & 4 & 1 & 0 & 0 \\
\hline 19 & Recommend & 0 & 0 & 0 & 0 & 0 & 0 & 0 & 0 & 0 \\
\hline 20 & Recommend & 3 & 1 & 0 & 2 & 0 & 0 & 0 & 0 & 0 \\
\hline
\end{tabular}

\begin{tabular}{|c|c|c|c|c|c|c|c|c|c|}
\hline \multirow{3}{*}{ Guideline } & \multirow{3}{*}{ Recommendation } & \multicolumn{8}{|c|}{ Supporting evidence } \\
\hline & & \multicolumn{4}{|c|}{ Evidence source of $\mathrm{SR} /$ meta-analysis } & \multicolumn{4}{|c|}{ Evidence source of original studies } \\
\hline & & $\begin{array}{l}\text { Children with } \\
\text { COVID-19 }\end{array}$ & $\begin{array}{l}\text { Patient with } \\
\text { COVID-19 }\end{array}$ & Other evidence & $\begin{array}{c}\text { The proportion of } \\
\text { direct evidence }\end{array}$ & $\begin{array}{l}\text { Children with } \\
\text { COVID-19 }\end{array}$ & $\begin{array}{l}\text { Patient with } \\
\text { COVID-19 }\end{array}$ & $\begin{array}{c}\text { Other } \\
\text { evidence }\end{array}$ & $\begin{array}{c}\text { The proportion of } \\
\text { direct evidence }\end{array}$ \\
\hline 1 & Recommend & 0 & 0 & 0 & NA & 0 & 0 & 1 & $0 \%$ \\
\hline 2 & Not recommend & 0 & 0 & 0 & NA & 0 & 0 & 0 & NA \\
\hline 3 & Recommend & 0 & 0 & 0 & NA & 0 & 1 & 0 & $0 \%$ \\
\hline 4 & Recommend & 0 & 0 & 0 & NA & 0 & 2 & 0 & $0 \%$ \\
\hline 5 & Not recommend & 0 & 0 & 0 & NA & 0 & 0 & 0 & NA \\
\hline 7 & Recommend & 0 & 0 & 0 & NA & 0 & 0 & 2 & $0 \%$ \\
\hline 8 & Recommend & 0 & 0 & 0 & NA & 0 & 0 & 0 & NA \\
\hline 9 & Not recommend & 0 & 0 & 0 & NA & 0 & 0 & 0 & NA \\
\hline 11 & Recommend & 0 & 0 & 0 & NA & 0 & 0 & 0 & NA \\
\hline 14 & Not recommend & 0 & 5 & 18 & $0 \%$ & 0 & 0 & 0 & NA \\
\hline 15 & Recommend & 0 & 0 & 0 & NA & 0 & 0 & 0 & NA \\
\hline 17 & Recommend & 0 & 0 & 65 & $0 \%$ & 1 & 5 & 9 & $7 \%$ \\
\hline 19 & Recommend & 0 & 0 & 0 & NA & 0 & 0 & 0 & NA \\
\hline 20 & Recommend & 0 & 0 & 0 & NA & 0 & 0 & 0 & NA \\
\hline
\end{tabular}

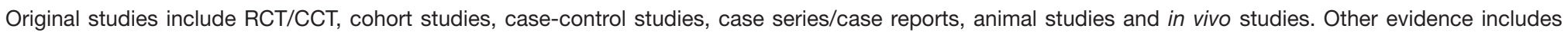

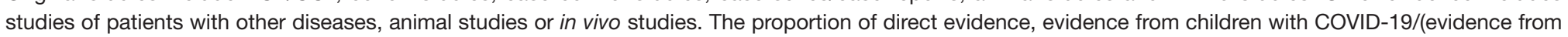
patients with COVID-19 + other evidence). NA, not applicable; CCT, clinical controlled trials; RCT, randomized controlled trials; SR, systematic review. 
Table S8 Summary of recommendations for intravenous immunoglobulin by included guidelines.

\begin{tabular}{|c|c|c|c|}
\hline Guideline & Recommendation & Indication & Dosing regimen \\
\hline 4 & Recommend & $\begin{array}{l}\text { MIS-C (KD features and/or coronary artery } \\
\text { changes) }\end{array}$ & $2 \mathrm{~g} / \mathrm{kg}$ (max dose 100g) \\
\hline 7 & Recommend & Severe COVID-19 & $\begin{array}{l}1 \mathrm{~g} / \mathrm{kg} / \text { day for } 2 \text { days, or } 400 \mathrm{mg} / \mathrm{kg} / \text { day for } \\
5 \text { days }\end{array}$ \\
\hline 9 & Not recommend & Not applicable & Not applicable \\
\hline 11 & Recommend & Severe COVID-19 & Not report \\
\hline 15 & Recommend & $\begin{array}{l}\text { Patients with KD-like illness, evidence of } \\
\text { excessive inflammation (ferritin }>700 \mathrm{ng} / \mathrm{mL} \text {, } \\
\mathrm{CRP}>30 \mathrm{~g} / \mathrm{dL} \text {, or multisystem organ failure), } \\
\text { or cardiac involvement. }\end{array}$ & $2 \mathrm{~g} / \mathrm{kg}$ \\
\hline 17 & Recommend & MIS-C & $1-2 \mathrm{~g} / \mathrm{kg}$ \\
\hline 19 & Not recommend & Not applicable & Not applicable \\
\hline 20 & Recommend & Severe and critical COVID-19 & $\begin{array}{l}1 \mathrm{~g} / \mathrm{kg} / \text { day for } 2 \text { days, or } 400 \mathrm{mg} / \mathrm{kg} / \text { day for } \\
5 \text { days }\end{array}$ \\
\hline
\end{tabular}

MIS-C, multisystem inflammatory syndrome in children; KD, Kawasaki disease; COVID-19, coronavirus disease 2019. 
Table S9 Summary of supporting evidences for recommendations for intravenous immunoglobulin

\begin{tabular}{|c|c|c|c|c|c|c|c|c|c|c|}
\hline \multirow[b]{2}{*}{ Guideline } & \multirow[b]{2}{*}{ Recommendation } & \multirow{2}{*}{$\begin{array}{c}\text { Reference } \\
\text { number }\end{array}$} & \multicolumn{8}{|c|}{ Study type of supporting evidence } \\
\hline & & & $\begin{array}{l}\text { Guidelines/ } \\
\text { consensuses }\end{array}$ & $\begin{array}{l}\text { SR/Meta- } \\
\text { analysis }\end{array}$ & Review & $\mathrm{RCT} / \mathrm{CCT}$ & $\begin{array}{l}\text { Cohort } \\
\text { studies }\end{array}$ & $\begin{array}{l}\text { Case-control } \\
\text { studies }\end{array}$ & $\begin{array}{l}\text { Case series/ } \\
\text { Case reports }\end{array}$ & $\begin{array}{l}\text { Animal studies/ } \\
\text { in vivo studies }\end{array}$ \\
\hline 2 & Not recommend & 0 & 0 & 0 & 0 & 0 & 0 & 0 & 0 & 0 \\
\hline 4 & Recommend & 0 & 0 & 0 & 0 & 0 & 0 & 0 & 0 & 0 \\
\hline 7 & Recommend & 0 & 0 & 0 & 0 & 0 & 0 & 0 & 0 & 0 \\
\hline 9 & Not recommend & 0 & 0 & 0 & 0 & 0 & 0 & 0 & 0 & 0 \\
\hline 11 & Recommend & 0 & 0 & 0 & 0 & 0 & 0 & 0 & 0 & 0 \\
\hline 12 & Not recommend & 0 & 0 & 0 & 0 & 0 & 0 & 0 & 0 & 0 \\
\hline 17 & Recommend & 9 & 3 & 1 & 1 & 3 & 0 & 0 & 1 & 0 \\
\hline 19 & Not recommend & 6 & 0 & 1 & 2 & 0 & 0 & 0 & 3 & 0 \\
\hline 20 & Recommend & 2 & 2 & 0 & 0 & 0 & 0 & 0 & 0 & 0 \\
\hline
\end{tabular}

\begin{tabular}{|c|c|c|c|c|c|c|c|c|c|}
\hline \multirow{3}{*}{ Guideline } & \multirow{3}{*}{ Recommendatiodsn } & \multicolumn{8}{|c|}{ Supporting evidence } \\
\hline & & \multicolumn{4}{|c|}{ Evidence source of SR/Meta-analysis } & \multicolumn{4}{|c|}{ Evidence source of original studies } \\
\hline & & $\begin{array}{l}\text { Children with } \\
\text { COVID-19 }\end{array}$ & $\begin{array}{l}\text { Patient with } \\
\text { COVID-19 }\end{array}$ & $\begin{array}{c}\text { Other } \\
\text { evidence }\end{array}$ & $\begin{array}{l}\text { The proportion of } \\
\text { direct evidence }\end{array}$ & $\begin{array}{l}\text { Children with } \\
\text { COVID-19 }\end{array}$ & $\begin{array}{l}\text { Patient with } \\
\text { COVID-19 }\end{array}$ & $\begin{array}{c}\text { Other } \\
\text { evidence }\end{array}$ & $\begin{array}{l}\text { The proportion of } \\
\text { direct evidence }\end{array}$ \\
\hline 1 & Recommend & 0 & 0 & 0 & NA & 0 & 0 & 0 & NA \\
\hline 2 & Not recommend & 0 & 0 & 0 & NA & 0 & 0 & 0 & NA \\
\hline 5 & Not recommend & 0 & 0 & 0 & NA & 0 & 0 & 0 & NA \\
\hline 7 & Recommend & 0 & 0 & 0 & NA & 0 & 0 & 0 & NA \\
\hline 9 & Not recommend & 0 & 0 & 0 & NA & 0 & 0 & 0 & NA \\
\hline 11 & Recommend & 0 & 0 & 0 & NA & 0 & 0 & 0 & NA \\
\hline 15 & Recommend & 0 & 0 & 0 & NA & 0 & 0 & 0 & NA \\
\hline 17 & Recommend & 0 & 0 & 13 & $0 \%$ & 0 & 1 & 4 & $0 \%$ \\
\hline 19 & Not recommend & 0 & 9 & 0 & $0 \%$ & 0 & 2 & 1 & $0 \%$ \\
\hline 20 & Recommend & 0 & 0 & 0 & NA & 0 & 0 & 0 & NA \\
\hline
\end{tabular}

Original studies include RCT/CCT, cohort studies, case-control studies, case series/case reports, animal studies and in vivo studies. Other evidence includes studies of patients with other diseases, animal studies or in vivo studies. The proportion of direct evidence, evidence from children with COVID-19/(evidence from patients with COVID-19 + other evidence). NA, not applicable; CCT, clinical controlled trials; RCT, randomized controlled trials; SR, systematic review. 
Table S10 Summary of recommendations for biologics by included guidelines

\begin{tabular}{|c|c|c|c|c|c|c|c|c|c|}
\hline \multirow[b]{2}{*}{ Guideline } & \multirow[b]{2}{*}{ Recommendation } & \multicolumn{2}{|l|}{ Anakinra (IL-1 inhibition) } & \multicolumn{2}{|l|}{ Tocilizumab (IL-6 inhibition) } & \multicolumn{2}{|c|}{ JAK inhibition } & \multicolumn{2}{|c|}{ Infliximab } \\
\hline & & Indication & Dosing regimen & Indication & Dosing regimen & Indication & $\begin{array}{l}\text { Dosing } \\
\text { regimen }\end{array}$ & Indication & Dosing regimen \\
\hline 4 & Recommend & $\begin{array}{l}\text { Fevers }>24 \text { hrs post steroids/ } \\
\text { IVIG or moderate/severe } \\
\text { presentation }\end{array}$ & $\begin{array}{l}2-4 \mathrm{mg} / \mathrm{kg} / \mathrm{dose} \text { ( } \max 100 \mathrm{mg} / \mathrm{dose}) \\
\text { SQ/IV BID, May } \uparrow \text { to TID or QID if poor } \\
\text { response } \\
\text { Continue for } 5-7 \text { days }\end{array}$ & $\begin{array}{l}\text { Consider adding to antiviral } \\
\text { therapy for patients meeting } \\
\text { criteria, criteria for risk high-risk } \\
\text { of cytokine storm }\end{array}$ & $\begin{array}{l}<30 \mathrm{~kg}: 12 \mathrm{mg} / \mathrm{kg} \text { IV; } \geq 30 \mathrm{~kg}: 8 \mathrm{mg} / \mathrm{kg} \\
\mathrm{IV} \text {, max } 800 \mathrm{mg} \text { (round dose to nearest } \\
\text { full vial) } \\
\text { Duration: One dose } \\
\text { Consider additional dose 8-12 } \\
\text { hours after if continued clinical } \\
\text { decompensation }\end{array}$ & Not report & Not report & Not report & Not report \\
\hline 8 & Recommend & $\begin{array}{l}\text { Severe/critical case with } \\
\text { evidence of hyperinflammation } \\
\text { (raised CRP, Ferritin, IL6, } \\
\text { sCD25) }\end{array}$ & $\begin{array}{l}\text { SC: } 2 \mathrm{mg} / \mathrm{kg} \text { once daily Increase dose by } \\
2 \mathrm{mg} / \mathrm{kg} \text { per day if unresponsive } \\
\text { Maximum dose } 8 \mathrm{mg} / \mathrm{kg} \text {, Stop if no clinical } \\
\text { benefit at maximum dose } \\
\text { IV: <20 } \mathrm{kg} 2 \mathrm{mg} / \mathrm{kg} \text { stat loading dose, } \\
\text { followed by a continuous infusion of } \\
0.02 \mathrm{~mL} / \mathrm{kg} / \mathrm{hr}(2 \mathrm{mg} / \mathrm{kg} / \text { day) } \\
>20 \mathrm{~kg} 2 \mathrm{mg} / \mathrm{kg} \text { stat loading dose, followed } \\
\text { by a continuous infusion of } 0.01 \mathrm{~mL} / \mathrm{kg} / \mathrm{hr} \\
(2 \mathrm{mg} / \mathrm{kg} / \text { day) } \\
\text { Increase by dose by } 2 \mathrm{mg} / \mathrm{kg} / \text { day every } 12 \\
\text { hours if unresponsive; } \\
\text { Maximum dose } 12 \mathrm{mg} / \mathrm{kg} / \text { day; Maximum } \\
\text { dose in } 24 \text { hours } 400 \mathrm{mg} \text { (excluding loading } \\
\text { dose) }\end{array}$ & $\begin{array}{l}\text { Severe/critical case with } \\
\text { evidence of hyperinflammation } \\
\text { (raised CRP, Ferritin, IL6, sCD25) }\end{array}$ & $\begin{array}{l}<30 \mathrm{~kg} 12 \mathrm{mg} / \mathrm{kg} \text {, IV } \\
>30 \mathrm{~kg} 8 \mathrm{mg} / \mathrm{kg} \text { (max dose } 800 \mathrm{mg} \text { ), IV } \\
\text { If no improvement at } 12 \text { hours, repeat } \\
\text { with same dose }\end{array}$ & Not report & Not report & Not report & Not report \\
\hline 15 & Recommend & $\begin{array}{l}\text { Patients have presented with } \\
\text { severe inflammation with or } \\
\text { without KD features consistent } \\
\text { with CSS in particular if they are } \\
\text { not responding to supportive } \\
\text { care or first line treatments }\end{array}$ & Not report & Not report & Not report & Not report & Not report & $\begin{array}{l}\text { If the presentation is } \\
\text { most consistent with } \\
\mathrm{KD} \text { and there is failure } \\
\text { of first line treatment }\end{array}$ & Not report \\
\hline 17 & Recommend & $\begin{array}{l}\text { MIS-C refractory to IVIG and } \\
\text { glucocorticoids or in patients } \\
\text { with contraindications to these } \\
\text { treatments }\end{array}$ & $\begin{array}{l}>4 \mathrm{mg} / \mathrm{kg} / \text { day IV or SQ } \\
\text { Time: Initiation of anakinra before invasive } \\
\text { mechanical ventilation may be beneficial }\end{array}$ & $\begin{array}{l}\text { COVID-19 pneumonia and signs } \\
\text { of hyperinflammation }\end{array}$ & $\begin{array}{l}<30 \mathrm{~kg}: 12 \mathrm{mg} / \mathrm{kg} \mathrm{IV} ; \geq 30 \mathrm{~kg}: 8 \mathrm{mg} / \mathrm{kg} \\
\text { IV, max } 800 \mathrm{mg}\end{array}$ & Not report & Not report & Not report & Not report \\
\hline 19 & Recommend & $\begin{array}{l}\text { Confirmed critical COVID-19 } \\
\text { (SARS-CoV-2 PCR } \\
\text { positive) with evidence of } \\
\text { hyperinflammation }\end{array}$ & Not report & $\begin{array}{l}\text { Confirmed critical COVID-19 } \\
\text { (SARS-CoV-2 PCR positive) with } \\
\text { evidence of hyperinflammation }\end{array}$ & Not report & $\begin{array}{l}\text { Not } \\
\text { recommend }\end{array}$ & $\begin{array}{l}\text { Not } \\
\text { applicable }\end{array}$ & Not report & Not report \\
\hline 20 & Recommend & Not applicable & Not applicable & Recommend & Not report & $\begin{array}{l}\text { Not } \\
\text { applicable }\end{array}$ & $\begin{array}{l}\text { Not } \\
\text { applicable }\end{array}$ & Not applicable & Not applicable \\
\hline
\end{tabular}


SARS-CoV-2, severe acute respiratory syndrome coronavirus 2. 
Table S11 Summary of recommendations for antiplatelet and anticoagulation drugs by included guidelines

\begin{tabular}{|c|c|c|c|c|c|c|c|}
\hline \multirow{2}{*}{ Guideline } & \multirow{2}{*}{ Recommendation - } & \multicolumn{2}{|r|}{ Aspirin } & \multicolumn{2}{|l|}{ Enoxaparin } & \multicolumn{2}{|l|}{ Warfarin } \\
\hline & & Indication & Dosing regimen & Indication & Dosing regimen & Indication & Dosing regimen \\
\hline 4 & Recommend & Not report & Not report & $\begin{array}{l}\text { COVID-19 patients unless } \\
\text { contraindicated }\end{array}$ & Not report & Not report & Not report \\
\hline 11 & Recommend & Not report & Not report & $\begin{array}{l}\text { Increased D-dimer and at high } \\
\text { risk of thrombosis }\end{array}$ & Not report & Not report & Not report \\
\hline 15 & Recommend & $\begin{array}{l}\text { Patients with KD-like illness, } \\
\text { evidence of excessive inflammation } \\
\text { (ferritin }>700 \mathrm{ng} / \mathrm{mL} \text {, CRP } \\
>30 \mathrm{~g} / \mathrm{dL} \text {, or multisystem organ } \\
\text { failure), or cardiac involvement. }\end{array}$ & $\begin{array}{l}20-25 \mathrm{mg} / \mathrm{kg} / \text { dose every } 6 \mathrm{~h} \\
\text { (80-100 mg/kg/day) IVIG: intravenous } \\
\text { immunoglobulin } \\
\text { CRP: C-reactive protein } \\
\text { CD-25: cluster of differentiation-25 } \\
\text { KD: Kawasaki disease } \\
\text { CSS: cytokine storm syndrome } \\
\text { COVID-19: coronavirus disease } 2019\end{array}$ & Not report & Not report & Not report & Not report \\
\hline 17 & Recommend & $\begin{array}{l}\text { MIS-C patients with CAAs and } \\
\text { a maximal z-score }>2.5 \text { and/or } \\
\text { thrombocytosis (platelet count } \\
\geq 450,000 / \mu \mathrm{L} \text { ) }\end{array}$ & $3-5 \mathrm{mg} / \mathrm{kg} /$ day; $\max 81 \mathrm{mg} /$ day & $\begin{array}{l}\text { MIS-C patients with CAAs and a } \\
\text { a } z \text {-score } \geq 10.0 \\
\text { Documented thrombosis or } \\
\text { ongoing moderate to severe LV } \\
\text { dysfunction }\end{array}$ & Not report & $\begin{array}{l}\text { MIS-C patients with CAAs and } \\
\text { a } z \text {-score } \geq 10.0 \\
\text { Documented thrombosis or } \\
\text { ongoing moderate to severe LV } \\
\text { dysfunction }\end{array}$ & Not report \\
\hline
\end{tabular}

IVIG, intravenous immunoglobulin; CRP, C-reactive protein; CD-25, cluster of differentiation-25; KD, Kawasaki disease; CSS, cytokine storm syndrome; COVID-19, coronavirus disease 2019. 